\title{
Nutrient management in African sorghum cropping systems: applying meta-analysis to assess yield and profitability
}

\author{
Christina Tonitto $^{1}$ - Jacob E. Ricker-Gilbert ${ }^{2}$
}

Accepted: 6 November 2015 / Published online: 10 February 2016

(C) INRA and Springer-Verlag France 2016

\begin{abstract}
Declining soil fertility and limited farmer access to inorganic fertilizer frequently cause sub-optimal grain yields throughout sub-Saharan Africa. Farm productivity is also at risk from extreme weather and future climate change. Significant uncertainty remains in predicting climate in Africa, increasing the challenge of planning for climate change adaptation. Sorghum is adapted to African climate patterns and is predicted to maintain widespread suitability across different African climatic zones under climate change. Sorghum's drought tolerance and ability to withstand water logging make it an important crop for maintaining productive agroecosystems under a changing climate. Due to its status as a staple grain, improved sorghum management can provide smallholder farmers with stability in their household nutritional needs. We reviewed sorghum (Sorghum bicolor) yield trends across nutrient management scenarios using meta-analysis. We compared yield across eight nutrient management practices: (i) N-only, (ii) P-only, (iii) $\mathrm{N}$ and $\mathrm{P}$, (iv) $\mathrm{N}$ and $\mathrm{P}$ microdose, (v) legume management, (vi) manure addition, (vii) organic matter (OM) amendment, and (viii) mixed amendment. Our review demonstrated (1) yield improvement considering all scenarios averaged $66 \%$ relative to no nutrient inputs, (2) yield under chemical fertilizer amendment increased
\end{abstract}

Christina Tonitto

ctonitto@cornell.edu; ctonitto@gmail.com

Jacob E. Ricker-Gilbert

jrickerg@purdue.edu

1 Cornell International Institute for Food, Agriculture and Development, Cornell University, B75 Mann Library, Ithaca, NY 14853, USA

2 Department of Agricultural Economics, Purdue University, 403 West State Street, West Lafayette, IN 47907, USA by $47-98 \%$ of control yield, (3) yield under organic nutrient amendment increased by $43-87 \%$ of control yield, and (4) the profitability of a management scenario was not solely determined by the magnitude of yield increase. For example, due to the high cost of fertilizer, addition of nitrogen $(\mathrm{N})$ and phosphorus $(\mathrm{P})$ generated the largest yield increase, but the lowest profit, in two of three countries analyzed. In contrast, an edible legume in rotation averaged $43 \%$ yield improvement relative to no nutrient inputs and a net profit of US \$146 to \$263 per hectare. Facilitating access to both fertilizer inputs and diversified rotations has the greatest potential to increase grain yield in Africa.

Keywords Africa $\cdot$ Sorghum bicolor $\cdot$ Sorghum yield · Nutrient amendment $\cdot$ Meta-analysis $\cdot$ Cropping system profitability $\cdot$ Sustainable livelihoods

$\begin{array}{ll}\text { Abbreviations } \\ \text { CI } & \text { Confidence intervals } \\ \text { FAO } & \text { Food and Agriculture Organization } \\ \text { ICRISAT } & \text { International Crops Research Institute for the } \\ & \text { Semi-Arid Tropics } \\ \text { MAP } & \text { Mean annual precipitation } \\ \text { N } & \text { Nitrogen } \\ \text { OM } & \text { Organic matter } \\ \text { P } & \text { Phosphorus } \\ \text { WUE } & \text { Water use efficiency }\end{array}$

\section{Contents}

1. Introduction

2. Methods

2.1 Systems compared, data sources, and compiled information

2.2 Meta-analysis 
2.3 Economic analysis

3. Results and discussion

3.1 Characterization of the published studies

3.2 Crop and yield trends

3.3 Meta-analysis limitations

3.4 Economic feasibility of management alternatives

3.5 Contextual agricultural development

4. Conclusions

Acknowledgements

References

\section{Introduction}

Improving crop yield and food self-sufficiency under increasing population pressure is a primary goal for attaining food security in Africa (Bremner 2012). At the same time, declining soil fertility is a dominant constraint toward achieving improved yield across Africa (Bosede 2010; Chianu et al. 2012; Mafongoya et al. 2006; Waddington et al. 2010). In addition, many farmers are unable to access inorganic fertilizer due to lack of credit, fertilizer's high cost, and general lack of policy and institutional support for fertilizer use (Chianu et al. 2012; Croppenstedt et al. 2003; Holloway et al. 2005). Therefore, African grain agroecosystems are commonly managed as low-input systems. Limited access of smallholder farmers to inorganic fertilizer or manure amendments is compounded by increased continuous cropping in response to food demand and population growth. Numerous African governments responded to the perception of low inorganic fertilizer use through a commitment to re-invest in agriculture. The resulting Abuja Declaration in 2006 called for an increase in inorganic fertilizer use by smallholder farmers in Africa. While there is evidence to suggest that inorganic fertilizer use has increased in recent years, low grain to fertilizer response rates caused by low soil fertility remains a challenge (Jayne and Rashid 2013; Sheahan and Barrett 2014).

Typical crop management planning which addresses soil fertility, pests, and water management, is further complicated by climate change. In the coming decades, climate change will build uncertainty into crop yield potential across Africa. A recent interdisciplinary workshop discussed how Saharan temperatures have increased at three times the global average over the past three decades, leading to the potential for famine and resource conflicts in Northern Africa and the Sahel (Claussen et al. 2015). Preparing for climate change is complicated by poor climate predictive capacity across Africa (Boko et al. 2007; Ramirez-Villegas and Challinor 2012), though climate researchers remain optimistic about potential for improvement of Africa climate modeling in the near term (Hansen et al. 2011; Ndiaye et al. 2011). Current predictions for crop yield response to climate change are varied, with yield decline predicted in some cases (Knox et al. 2012; Schlenker and Lobell 2010; Zinyengere et al. 2013), and yield improvement or maintenance predicted in other scenarios (Liu et al. 2008; Roudier et al. 2011).

Sorghum is a broadly suitable grain for African agroecosystems. Due to its evolutionary origin as an East African tropical cereal grass, sorghum is adapted to African climate patterns. In particular, sorghum is tolerant to both drought as well as extensive periods of water logging, conditions which are common in semi-arid and sub-tropical climate regions of African arable landscapes (Edmonds et al. 2009). Ramirez-Villegas et al. (2011) mapped the current widespread suitability of sorghum in sub-Saharan Africa using data compiled by the Food and Agriculture Organization (FAO) and the International Crops Research Institute for the Semi-Arid Tropics (ICRISAT). They projected that sorghum will continue to be suitable throughout much of its current range under climate change. While traditional sorghum-growing regions of East Africa have increasingly grown maize over the last half century, promoting successful sorghum management strategies is an important component of food security. Multiple studies of maize and sorghum under medium to severe water stress conditions demonstrated that sorghum yield can be higher than maize yield under drought stress as well as more profitable (Farré and Faci 2006; Schittenhelm and Schroetter 2014; Staggenborg et al. 2008). Sorghum's tolerance to variable weather patterns was also observed in a recent assessment of crop growth in response to decadal variation in temperature and rainfall in Mali, which indicated that sorghum yield variation was not correlated to weather patterns, while maize yield was positively correlated with rainfall (Traore et al. 2013). While a recent field experiment found maize to produce higher yields than sorghum and millet following variable seasonal rainfall distribution conditions in Zimbabwe (Rurinda et al. 2014), field studies in Mali indicated maize sensitivity to erratic rainfall conditions (Traore et al. 2014). Figure 1a illustrates that well-managed sorghum can be a high-yielding crop and Fig. 1b illustrates sorghum in a diversified smallholder cropping system. In addition to suitability to African climate, sorghum has a higher level of nutritional carbohydrates content, lower fat content, and higher iron content than maize (Rurinda et al. 2014, p. 38). Sorghum is also a staple in a variety of nutritious traditional foods in many parts of Africa (Dicko et al. 2006; Elkhalifa 2012). Nutritional benefits combined with tolerance to adverse weather conditions make efforts to improve sorghum productivity an essential component for increasing African agricultural productivity and household food security in the twenty-first century.

With these considerations in mind, we conducted a metaanalysis of sorghum yield in Africa to quantify the effect of various nutrient management strategies on improving crop yield. We subsequently addressed the economic feasibility of these nutrient amendment scenarios in three representative 

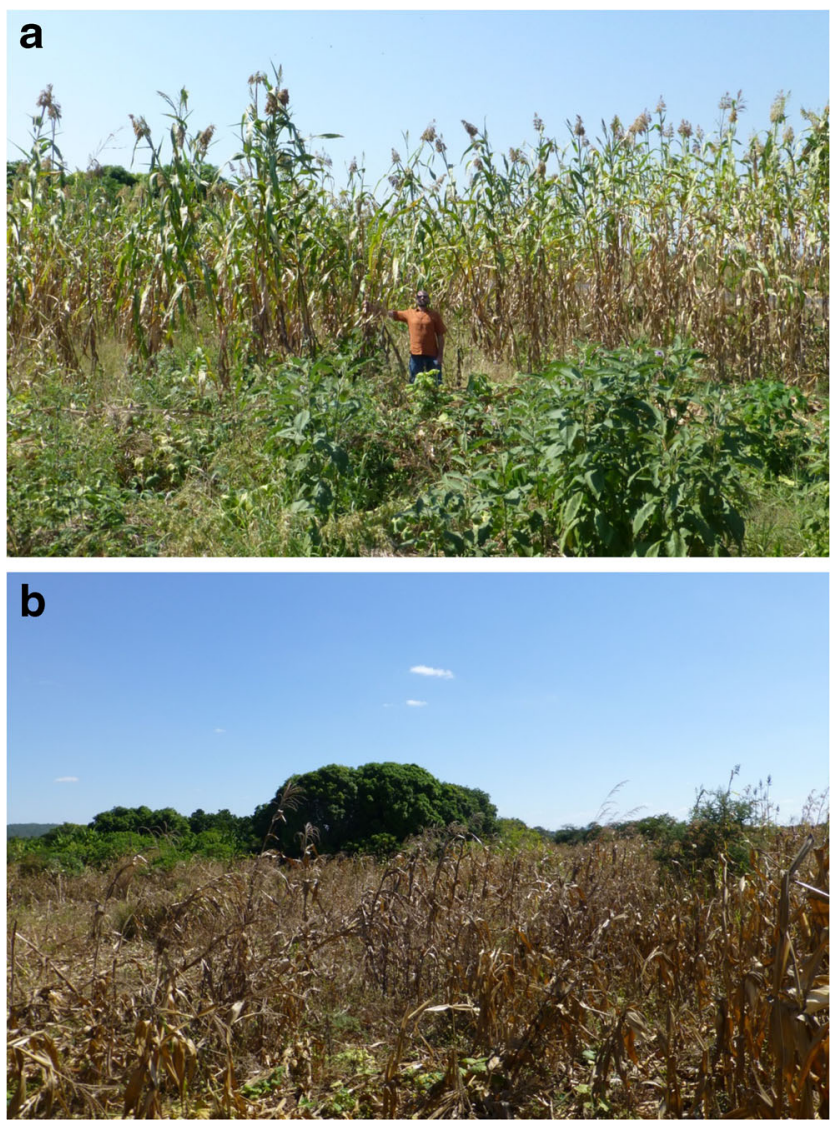

Fig. 1 Sorghum cropping systems in eastern province of Zambia. a Sorghum growing under favorable conditions. b A diversified smallholder farm growing, sorghum along with maize, groundnuts, squash, okra, and cotton. (Photo courtesy of Noel Gurwick, USAID)

countries: Burkina Faso, Ethiopia, and Zimbabwe (discussed in section 2.3). We expect that all nutrient amendment strategies will improve yield relative to the common occurrence of no nutrient amendment. We applied meta-analysis to test whether the conventional Green Revolution strategy of agronomic optimal fertilizer application leads to the highest yields, as well as the extent to which alternatives to inorganic fertilizer application improve yield. Our combined agronomic and economic analysis outlines when farmers will benefit most from convention strategies versus alternative nutrient management such as Integrated Soil Fertility Management (ISFM) promoted by the Alliance for a Green Revolution in Africa (AGRA) (Vanlauwe et al. 2012; Vanlauwe 2013). We conclude with a discussion of these quantitative outcomes in the context of agroecosystem management for mitigation of pests, environmental uncertainty, and climate change. Meta-analysis techniques differ from a more general literature review in that meta-analysis requires a strict comparison of paired control and treatment data points. Recent literature has identified meta-analysis as a tool that fundamentally changed how scientists synthesize data trends, allowing researchers to compare consistencies and inconsistencies across individual experiments, assess how well data fit theory, and identify research gaps (Koricheva and Gurevitch 2014; Nakagawa and Santos 2012). The findings in this study provide important insights into appropriate agronomic and economic nutrient management practices that can help farmers profitably manage sorghum production in response to declining soil fertility.

\section{Methods}

\subsection{Systems compared, data sources, and compiled information}

The application of meta-analysis techniques requires that each study compares a control to an experimental treatment and that these control and treatment scenarios can be consistently defined across studies. In order to compare the response of sorghum yield to a range of amendment techniques, we defined the control treatment as the common practice of no nutrient inputs. We contrasted this control system to sorghum systems with nutrient amendments conducting our main categorical analysis to look at the impact of nutrient amendment strategies grouped into eight categories: (1) $\mathrm{N}$ addition, (2) P addition, (3) $\mathrm{N}$ and $\mathrm{P}$ addition, (4) microdose of $\mathrm{N}$ and $\mathrm{P}$, (5) legume management, (6) manure addition, (7) organic matter $(\mathrm{OM})$ amendment, and (8) mixed amendment.

We compiled data from the peer-reviewed literature using field studies that compared sorghum yields from fields without nutrient inputs to yields under various nutrient amendment strategies for field observations from Sahelian, SudanoSahelilan, Sudanian, and Eastern Africa. We searched the Web of Science database using the search terms ("sorghum" and "yield" and "Africa") as well as ("sorghum" and "productivity" and "Africa") to locate field outcomes reporting yield across management techniques; the search resulted in 296 and 86 articles, respectively. To be included in this analysis studies had to have a field without nutrient amendment (the control) compared to at least one nutrient amendment scenario (inorganic fertilizer, legume, manure, or OM amendment). We extracted sorghum yield outcomes from articles meeting these criteria. A total of 29 publications met the criteria for inclusion in this study, these data represent 33 study sites and 165 paired yield outcomes. Multiple data pairs from a single publication qualified for inclusion in our meta-analysis because individual publications generally reported outcomes from multiple sites and for multiple treatment scenarios. Each data pair is from a different field and represents an outcome experiencing unique environmental conditions. The majority of the experiments were conducted as on-farm trials (45\%) and represent yield outcomes averaged over multiple fields. The remaining field trials were conducted at experimental stations (30\%) and on lands representative of regional agricultural landscapes (25\%). Because study fields represent unique locations and 
the data are from a broad distribution of environmental conditions, the potential for data non-independence to drive yield trends is minimal. When studies reported the Sorghum bicolor variety used, it was indicated that locally relevant varieties were planted. Many studies were from farmer fields. In cases where experiments were conducted on research farms, we expect that common regional varieties were studied such that results would reflect farmer experience. While sorghum variety can greatly influence maximum potential yield, the change in yield between control and treatment fields (the metric of our analysis) remains a useful tool to compare relative impact of nutrient amendment across studies. Because different sites use different regional varieties we do not have sufficient data to consider variety for a categorical analysis. Table 1 lists the studies used in this meta-analysis. Section 3.1 describes the characteristics of the data used in this study.

As part of our data compilation and analysis, we categorized the following factors in our database: mean annual precipitation (MAP), soil texture, and $\mathrm{N}$ or $\mathrm{P}$ rate. In addition to our main comparison of nutrient amendment sub-groups, we contrast change in yield across soil texture sub-groups categorized as heavy (clay + clay loam), medium (loam + silt loam + sandy clay), or light (sand + loamy sand + sandy loam + sandy clay loam). Because many studies did not report the form of fertilizer used, we had insufficient data to conduct a sub-group analysis of the impact of fertilizer type.

\subsection{Meta-analysis}

Meta-analysis is a tool for quantifying trends across systems characterized by different summary statistics. This property of meta-analysis allowed us to compare sorghum yield across broad climate, soil types, and amendment protocols. To conduct a meta-analysis, an effect size estimator is calculated as an index for comparing the experimental treatment mean to the control treatment mean (Gurevitch and Hedges 1999; Philibert et al. 2012; Koricheva and Gurevitch 2014). Ultimately, the effect size estimator allows us to quantify the magnitude of a treatment effect. We calculated our effect size using the response ratio $(r=\overline{X e} / \overline{X c})$, which is the relative impact of nutrient amendment (the experimental treatment $X e$ ) compared to a cropping system with no nutrient inputs (the control treatment $X c$ ). The response ratio is a typical effect size applied in ecological studies focused on the change in productivity across treatments (e.g., Johnson and Curtis 2001; Koricheva and Gurevitch 2014). In order to perform the meta-analysis on normally distributed data, we used a $\log$ transformation of the response ratio, $R=\ln (r)=\ln (\overline{X e})-$ $\ln (\overline{X c})$. For analyses where $\overline{X c}$ is constrained to nonnegative values and where $\overline{X e}$ and $\overline{X c}$ are normally distributed, such as the application presented here, $R$ should be approximately normally distributed with a mean approximately equal to the true response ratio (Johnson and Curtis 2001). To facilitate the interpretation of the change in yield across treatments, meta-analysis results are graphically presented using backtransformed response ratios such that the change in yield is reported in percent deviation from the control yield (e.g., Johnson and Curtis 2001); this is calculated as change in yield $(\%)=100 \times((X e / X c)-1)$. We conducted our meta-analysis using MetaWin version 2.1 software (Rosenberg et al. 2000).

Because nearly all of the studies we used did not report a measure of variance, we conducted an unweighted metaanalysis using a fixed-effects model. The statistical significance of our unweighted meta-analysis was enhanced by the calculation of confidence intervals (CI). After a mean effect size was calculated, a bias-corrected $95 \%$ confidence interval was generated by a bootstrapping procedure (5000 iterations) using the MetaWin software (Rosenberg et al. 2000). Using meta-analysis, we explored the mean response ratio using soil texture as a categorical variable. Means were considered to be significantly different from one another if their bias-corrected $95 \%$ CIs were non-overlapping and were considered significantly different from zero if the bias-corrected $95 \%$ CI did not overlap zero (Gurevitch and Hedges 1999; Johnson and Curtis 2001).

We assessed publication bias by comparing how effect size varied across increasing replication in experimental design. Effect sizes measured using the log response ratio ranged from $-1<R<2$, indicating that experiments with negative results are included in the peer-reviewed literature. As replication increased, effect size narrowed with the majority of values ranging from $0<R<1$. The data indicate that non-significant experimental results were published and that increasing replication reduced the influence of outlier results on aggregate outcomes. We did not find evidence of publication bias in the data used in this analysis for two main reasons. First, most outcomes cluster around moderate yield improvement following nutrient inputs, and second, data included negative yield outcomes and exhibited outlier outcomes only for lowreplication studies.

\subsection{Economic analysis}

We recognize that nutrient amendment is a significant expense for African smallholder farmers. Therefore, we compared the net profit of applying the nutrient management techniques studied in our meta-analysis to outline circumstances under which a given amendment strategy is possible and favorable. We calculated economic profitability of different management scenarios based on sorghum output prices and fertilizer costs using price data for Burkina Faso, Ethiopia, and Zimbabwe. These countries cover west, east, and southern Africa, respectively. We chose these example countries for our economic analysis because (1) Burkina Faso and Zimbabwe are the most represented countries in 


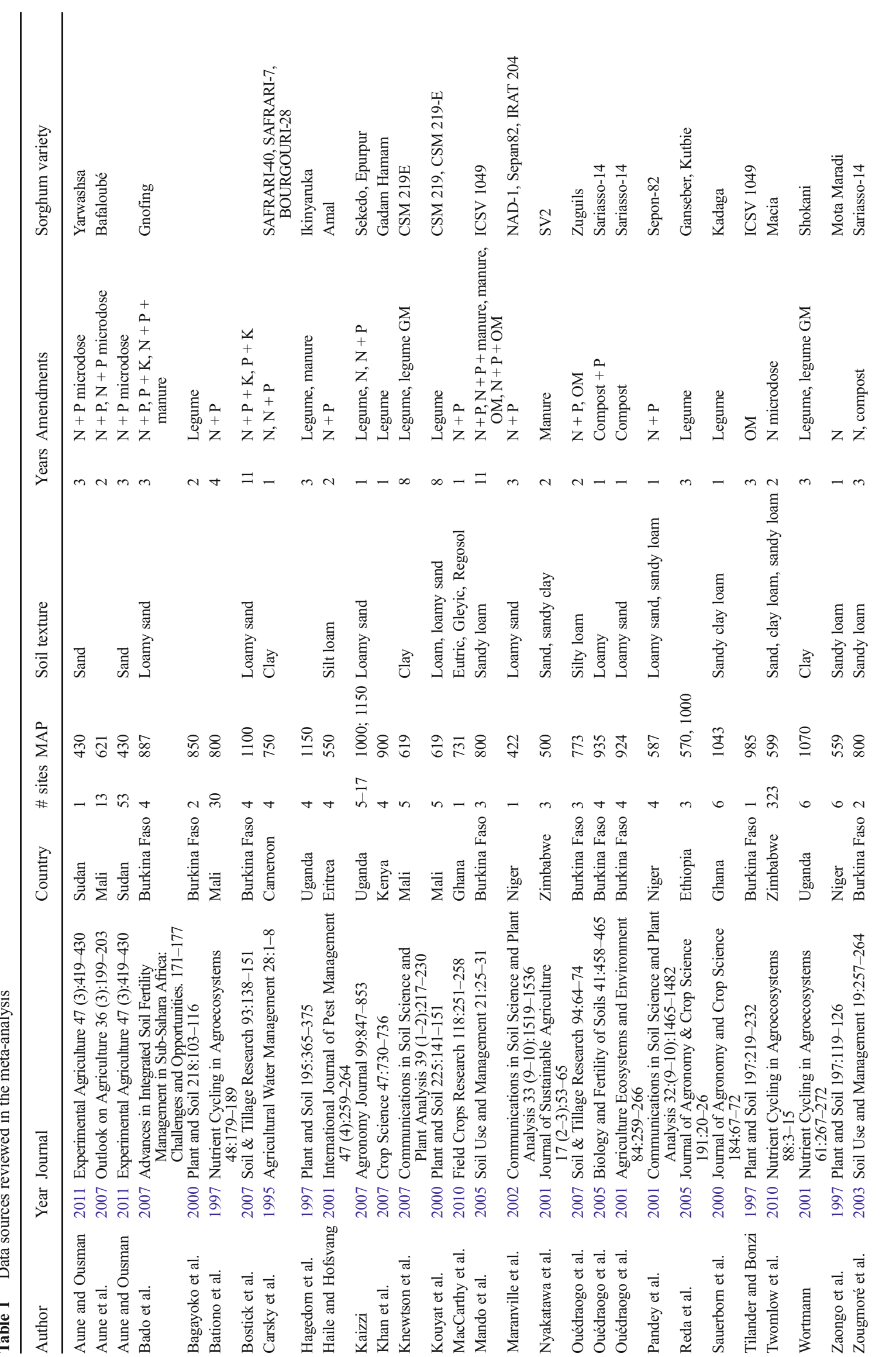


the yield database used for our meta-analysis, (2) sorghum provides greater than one third of total caloric intake in Burkina Faso (Aguado-Santacruz et al. 2012), (3) sorghum is believed to have evolved in Ethiopia (Aguado-Santacruz et al. 2012; Dicko et al. 2006), and (4) there are a number of traditional sorghum-based foods in Ethiopia (Dicko et al. 2006; Elkhalifa 2012).

We calculated sorghum profitability under four different management treatments: (1) $\mathrm{N}$ addition, (2) $\mathrm{N}$ and $\mathrm{P}$ addition, (3) microdose of $\mathrm{N}$ and $\mathrm{P}$, and (4) legume management; these four treatments are the most common treatments applied in our meta-analysis, accounting for $72 \%$ of our database. We calculated the profitability of different sorghum nutrient amendment treatments as a net return per hectare. For the three countries assessed, we calculated the (1) increase in grain revenue, (2) cost of fertilizer management, (3) cost of legume management, and (4) net return for a field in country $(i)$ managed under each of the four treatments $(j)$ as:

1. Grain revenue e $_{i, i}(\mathrm{ha})=\left(\right.$ price sorghum $\left._{\mathrm{i}}\right) \times($ yield differential $\left._{i, j}(\mathrm{ha})\right)$

2. Cost of nutrient management treatment $i, j(\mathrm{ha})=$ cost of fertilizer $\operatorname{applied}_{i, j}(\mathrm{ha})$

3. Cost of legume management treatment $t_{i, j}(\mathrm{ha})=$ cost of cowpea (0.5 ha)

4. Net return ${ }_{i, j}(\mathrm{ha})=$ grain revenue $_{i, j}(\mathrm{ha})-\operatorname{cost}_{i, j}(\mathrm{ha})$

To calculate grain revenue, we use the meta-analysis outcomes to derive the yield differential relative to the control resulting from treatment $j$. We derived yield differentials by taking the country-specific mean yield for the control treatment and varying this yield by the percent improvement under a specific management treatment quantified in the meta-analysis. We then multiplied yield differential values derived from the meta-analysis with country-specific sorghum and cowpea price data from the Food and Agricultural Organization Statistics (FAOSTAT 2012) and household surveys (Ethiopian Rural Household Survey 2009 for Ethiopia, ICRISAT Sorghum Macia Impact Assessment Survey 2013 for Zimbabwe). To assess the cost of nutrient amendment treatment, the cost of treatment $j$ in country $i$ was calculated as the cost per hectare of the median fertilizer treatment rate applied in the meta-analysis database. In our cost calculations, we used fertilizer price data from AfricaFertilizer.org (Africa Fertilizer 2012) for Burkina Faso (monthly price data from 2010-2012) and household survey data for Ethiopia (sampled in 2009) and Zimbabwe (sampled in 2013). For legume management, we considered two scenarios. Under legume intercropping, the primary crop is sorghum; while cowpea is planted with the sorghum, we do not consider cowpea sales in this scenario, using this scenario to represent cowpea used for animal fodder or soil amendment. The second scenario was addition of legumes in a rotation, in which we assumed a farmer sowed 0.5 ha to sorghum and 0.5 ha to cowpea in a given growing season; the per hectare net return for this rotation was conducted using grain revenue and management costs for a hectare equally split between sorghum and cowpea management. Management under legume intercropping or legume rotation does not include fertilizer application. We included the cost of cowpea seed in our assessment of legume management. We assume the upper seeding rate recommended in Dugje et al. (2009) of $25 \mathrm{~kg} \mathrm{ha}^{-1}$ would apply for a hectare of pure cowpea and, therefore, use a conservative estimate of $12.5 \mathrm{~kg} \mathrm{ha}^{-1}$ for the intercropping and rotation cost analysis. We use a cowpea seed cost of $\$ 1 \mathrm{~kg}^{-1}$ based on the conventional cowpea seed price of $\$ 0.80$ (Burkina Faso), \$1 (Niger), and \$0.60 (Nigeria) per kilogram reported in Coulibaly (2008).

We conducted a sensitivity analysis of profitability to changes in fertilizer cost. We establish the break-even cost of fertilizer across inorganic fertilizer treatments as the fertilizer cost when profit equals zero. Therefore, for profit $=$ revenue cost, at the break-even point revenue $=$ cost. For scenarios with a single fertilizer type applied, the break-even price $=$ revenue/ (fertilizer application rate). For the $\mathrm{N}$ and $\mathrm{P}$ treatment, we hold the $\mathrm{N}$ fertilizer price constant and establish the break-even price for a combined N and P fertilizer source (NPK, DAP, or Compound D).

The economic scenarios presented in this analysis are simplifications that do not consider all costs (both direct and opportunity costs) and benefits of different treatments. We do not price sorghum seed as we assume that the cost of sorghum seed would be the same regardless of amendment strategy. We also do not assess labor costs or issues surrounding farmer access to markets. Though our economic analysis does not examine all constraints placed on the farmer, this aggregate comparison of regional differences in grain revenues and management costs illustrates that potential yield increase per hectare is not sufficient information for selecting the most profitable sorghum nutrient management strategy.

\section{Results and discussion}

\subsection{Characterization of the published studies}

Our analysis included data from 33 study sites representing 11 countries across Sahelian, Sudano-Sahelilan, Sudanian, and Eastern Africa. The mean annual precipitation (MAP) gradient ranged from $430 \mathrm{~mm}$ to $1150 \mathrm{~mm}$; rainfall occurred in a single season for MAP $<900 \mathrm{~mm}$ and in two seasons for $M A P \geq 900 \mathrm{~mm}$. No studies applied irrigation. Loamy sand was the dominant soil texture, characterizing $45 \%$ of the study sites. Overall, light soil texture characterized $69 \%$ of the sites, medium textured soils characterized $26 \%$ of sites, and heavy textured soils characterized $10 \%$ of the sites. Studies using $\mathrm{N}$ and $\mathrm{P}$ amendment comprised the largest category of data fitting our constraints, legume management was the second most common amendment strategy, $\mathrm{N}$-only 
amendment the third largest, $\mathrm{N}$ and $\mathrm{P}$ microdosing the fourth largest, amendment with manure or OM tied for fifth, and Ponly amendment was the smallest category. Urea was the most commonly applied synthetic fertilizer, used at $30 \%$ of sites where fertilizer was applied; ammonium nitrate was the next most common fertilizer type, applied at $10 \%$ of fertilized sites. Total $\mathrm{N}$ applied in fertilizer was reported in all studies, but $23 \%$ of sites did not report fertilizer type. Fertilizer application rate varied over a narrow range in $\mathrm{N}$-only and microdose studies, but there was a wider range of $\mathrm{N}$ applied across treatments with $\mathrm{N}$ and $\mathrm{P}$. We include the full range of experimental nutrient application rate in our analysis as the literature does not indicate regional optimal application rate and the highest application rates are within the range recommended for grain sorghum grown in temperate climates. Furthermore, yield improvement was not fully explained by nutrient application rates, with high relative yield improvements achieved under intermediate nutrient application rates (discussed below). The majority of yield trials were conducted as short-term studies (47\% 1 year, $15 \% 2$ years, $22 \%$ 3 years); trials greater than 8 years in duration constitute $10 \%$ of the data. Many studies report aggregate yield data from multiple on-farm trials; $62 \%$ of data pairs extracted from the reviewed literature are aggregate results of mean observations across 4-10 field sites. The largest on-farm study was conducted in Zimbabwe and included over 300 field trials (Twomlow et al. 2010).

\subsection{Crop yield trends}

For control fields (fields with no nutrient amendment), the mean and range of sorghum yield was similar across the MAP gradient (Fig. 2). Under nutrient amendment, there was a significant overlap in the range of sorghum yield across the MAP gradient, with the mean yield showing considerable increase under the highest MAP category corresponding to agroecosystems with two rainy seasons (Fig. 2). Amendment with $\mathrm{N}$ and $\mathrm{P}$ resulted in a significant yield improvement for all levels of nutrient inputs - from the low application rates observed in microdosing studies through studies applying excess fertilizer (Fig. 3a). Linear regression was conducted to assess the suitability of nutrient application rate for determining the change in yield on coarse textured soils; studies on medium and fine-textured soils tested a narrow range of nutrient application rate and were not suitable for regression analysis. Simple linear re gression indicated $\mathrm{N}$ input rate was a good indicator of change in yield in systems with a single rainy season (Fig. 3b); the relationship between $\mathrm{P}$ added and change in yield was inconsistent, in part due to limited variation in $\mathrm{P}$ application rate in systems with moderate or high annual rainfall (Fig. 3c).

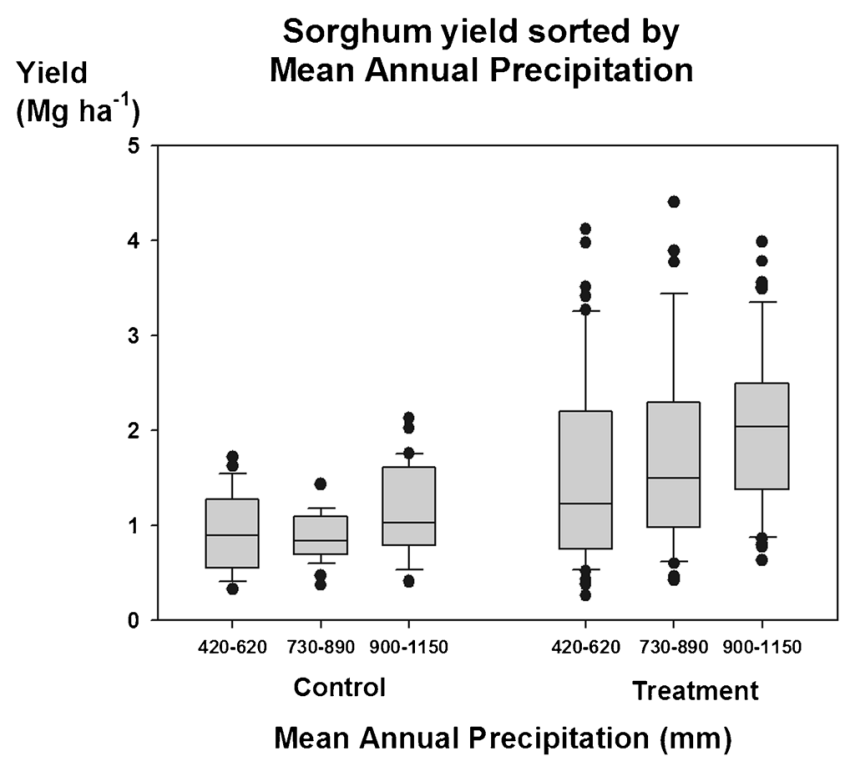

Fig. 2 Distribution of sorghum yield across a mean annual precipitation (MAP) gradient for control and treatment fields

Our quantitative review of the peer-reviewed literature using meta-analysis concluded that nutrient management techniques averaged a $66 \%$ yield improvement relative to no nutrient inputs (Fig. 4). Amendment with $\mathrm{N}$ and $\mathrm{P}$ fertilizer resulted in the highest yield improvement, averaging $98 \%$ improvement relative to the control scenario. Relative to the control, amendment with $\mathrm{N}$-only, P-only, or manure improved yield by 72,72 , and $87 \%$, respectively, with the $95 \%$ confidence intervals showing a significant overlap with the highest yielding $\mathrm{N}$ and $\mathrm{P}$ amendment category. On average, including legumes in a rotation improved yield by $43 \%$, OM amendment improved yield by $47 \%$, and microdose application improved yield by $47 \%$ relative to management with no nutrient inputs. Amendment using both synthetic fertilizer and an organic $\mathrm{N}$ source averaged an $80 \%$ yield improvement, with this mixed treatment category exhibiting a large range in outcomes. Figure 5 illustrates the distribution of observed change in yield as a result of nutrient management. Approximately $12 \%$ of observations showed a small yield response to nutrient management, with $6 \%$ of observations exhibiting a yield decrease ranging from -15 to $0 \%$ change and $6 \%$ of observations exhibiting a yield increase ranging from 0 to $15 \%$ change relative to control yield. In most studies, a substantial yield increase was observed under nutrient management treatments, with a range of $15-30 \%$ increase occurring in $12 \%$ of observations, a $30-50 \%$ increase documented in $16 \%$ of observations, a $50-75 \%$ increase documented in $13 \%$ of observations, a $75-100 \%$ increase documented in $11 \%$ of observations, and $>100 \%$ increase documented in almost $32 \%$ of observations.

We assessed heterogeneity of the compiled dataset using the meta-analysis statistic Q; this analysis yielded non-significant $p$ values within nutrient treatment sub-groups. A non- 
Fig. 3 Change in yield across the range of $\mathrm{N}$ and $\mathrm{P}$ amendment applied. a Change in yield as a function of $\mathrm{N}$ and $\mathrm{P}$ input. $\mathbf{b} \mathrm{A}$ regression analysis of $\mathrm{N}$

amendment on change in yield, which was significant for MAP of 420-620 $\mathrm{mm}\left(R^{2}=0.59\right)$ and MAP of $700-900\left(R^{2}=0.71\right)$. $\mathrm{A}$ regression analysis of $\mathrm{P}$ amendment on change in yield, which was not significant. All observations are for coarsetextured soils a

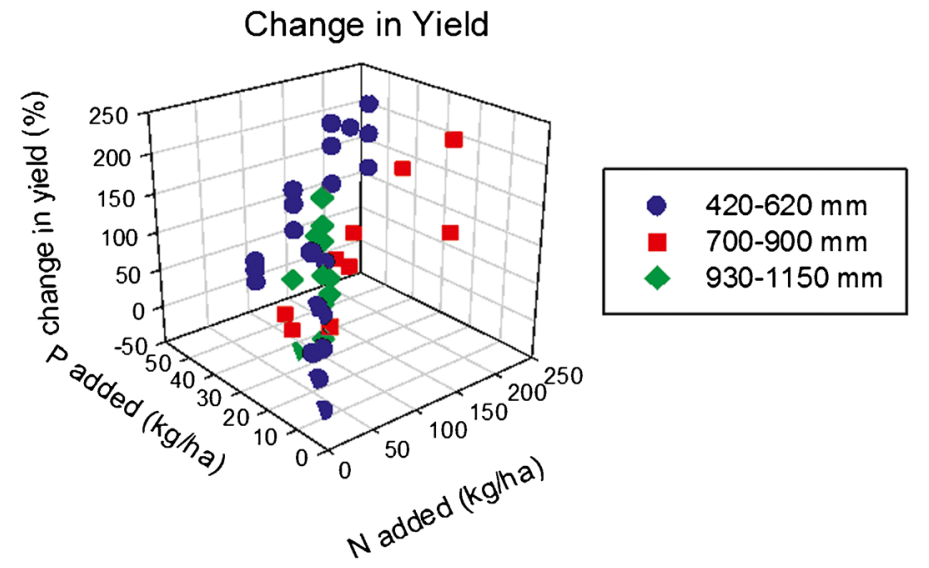

b
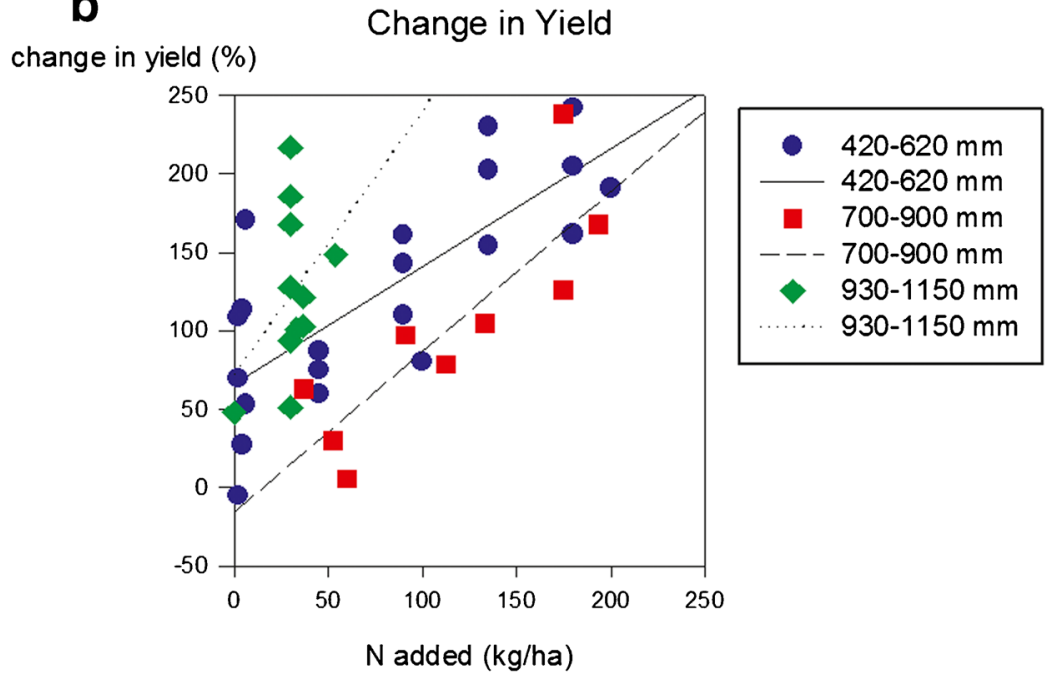

C

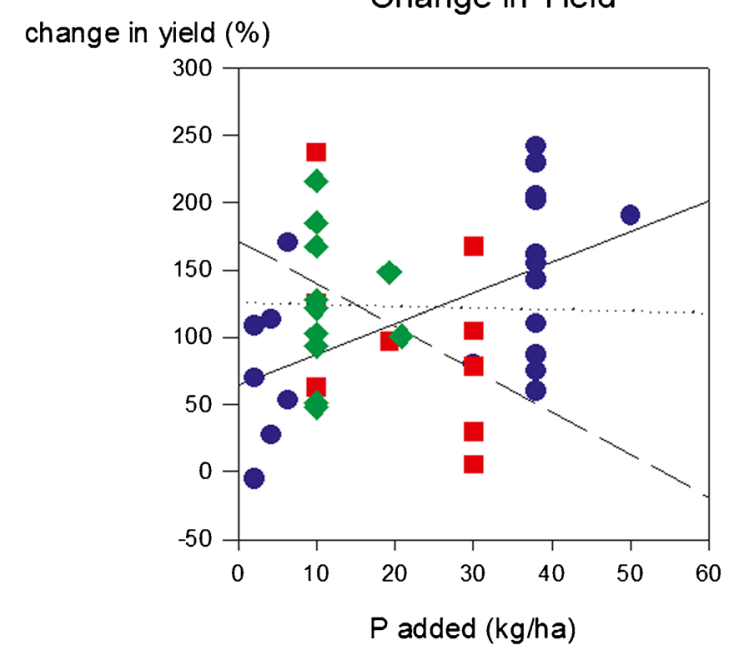

significant $Q$ statistic indicates that we cannot refute the hypothesis that the effect size is representative of the respective nutrient treatment effect; the $Q$ statistic cannot be used to prove the effect size is the true treatment effect size. The between treatment group $Q$ statistic was also non-significant, concurring with the significant overlap in the confidence intervals across treatment sub-categories (Fig. 4). Because many of the studies we surveyed did not indicate experimental variance, we conducted an unweighted meta-analysis; as a result, further heterogeneity analysis using the $\tau$ statistic was not 
Change in yield across Management nutrient amendment practices category

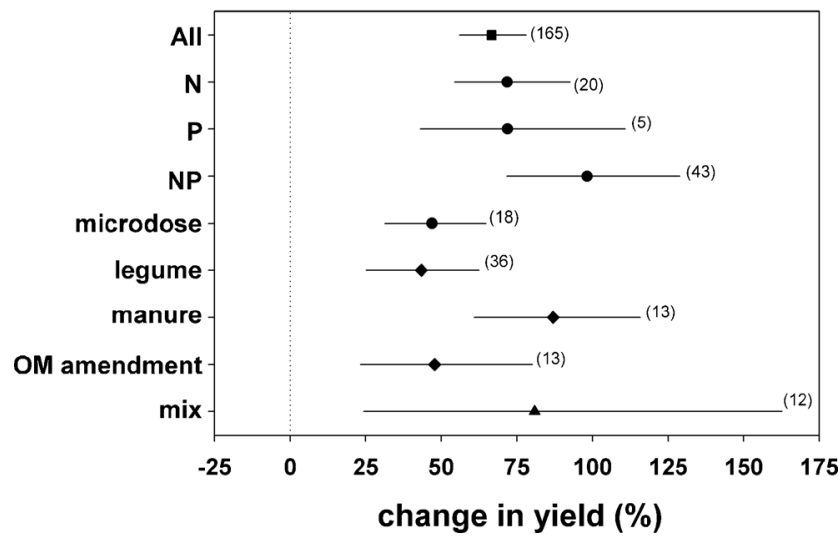

Fig. 4 Percent change in yield across nutrient amendment scenarios. Effect of nutrient amendment on sorghum yield in units of percent change from the control (no nutrient inputs) grouped by amendment category. Mean values and $95 \%$ confidence intervals of the backtransformed response ratios are shown (number of comparisons in parentheses). Square icon represents data from all practices, circles are inorganic fertilizer, diamonds are organic nutrient amendments, and the triangle represents mixed amendment

warranted. Rather, the variance in the data analysis is best illustrated by the meta-analysis confidence intervals (Fig. 4).

Light-textured soils represented $69 \%$ of the data pairs and resulted in significantly larger yield improvements relative to medium- or heavy-textured soils (Fig. 6). Light-textured soils are fast draining and therefore subject to greater soil moisture stress. Due to this physical soil property, light-textured soils extract greater benefit from organic matter amendment with regard to water retention. The light-textured soil category

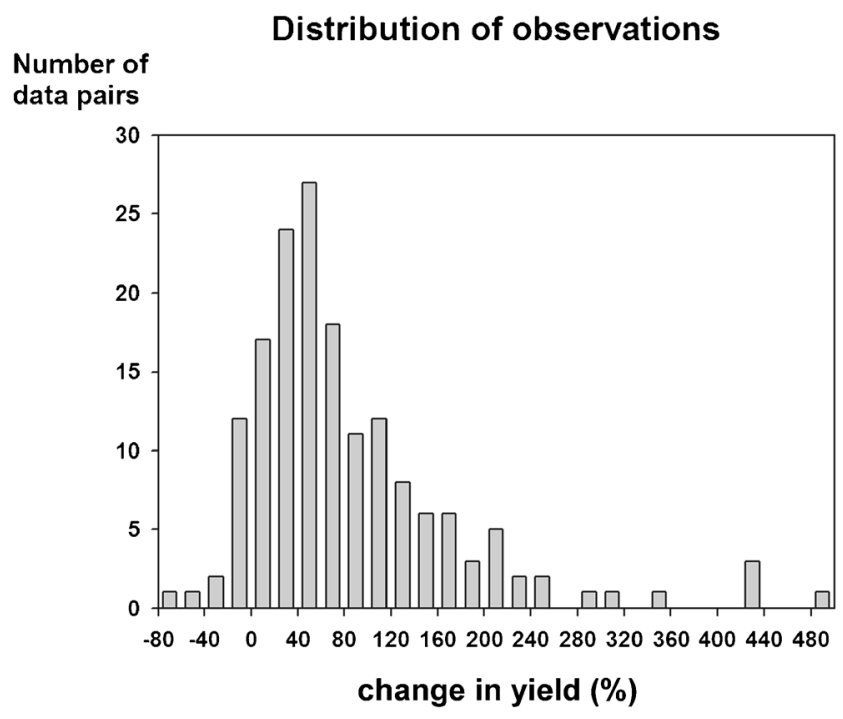

Fig. 5 Distribution of observed change in yield as a result of nutrient management. Histogram shows the frequency of percent change in yield resulting across all management treatments for bins in 20 percentile increments includes observations of significant yield gains from legume, manure, and $\mathrm{OM}$ amendment, which likely demonstrates the co-benefit of these management practices with respect to increasing plant access to both macro- and micronutrients, as well as water. Similar to heterogeneity analysis of the nutrient treatment sub-group categorization, the $Q$ statistic was nonsignificant within a texture sub-group. However, the betweengroup $Q$ statistic was significant, indicating effect size was significantly different across soil texture sub-groupings. Because light-textured soil is the dominant field condition across studies in our database, the overall treatment effect size is weighted toward the outcomes for light-textured soils.

\subsection{Meta-analysis limitations}

The ability to extract a mechanistic understanding of trends observed in meta-analysis is limited by data quality and comparability. In this example, all studies indicated nutrient amendment type, allowing us to quantify how different amendment practices impacted yield. However, other crop management details that we know impact yield were not described in the literature, preventing us from exploring additional mechanistic drivers of yield. Even in cases where the literature includes information about mechanistic drivers, the experimental design may not lend to comparison. For instance, we did not have sufficient data to compare the impact of inorganic fertilizer form or sorghum variety on yield trends. Meta-analysis relies on extracting data from experiments that are conducted with different hypotheses. While studies that are focused on yield outcomes generally have similar fundamentals in their design, the studies will all have slight differences in methods.

\section{Change in yield across soil textures}

\section{Soil texture}

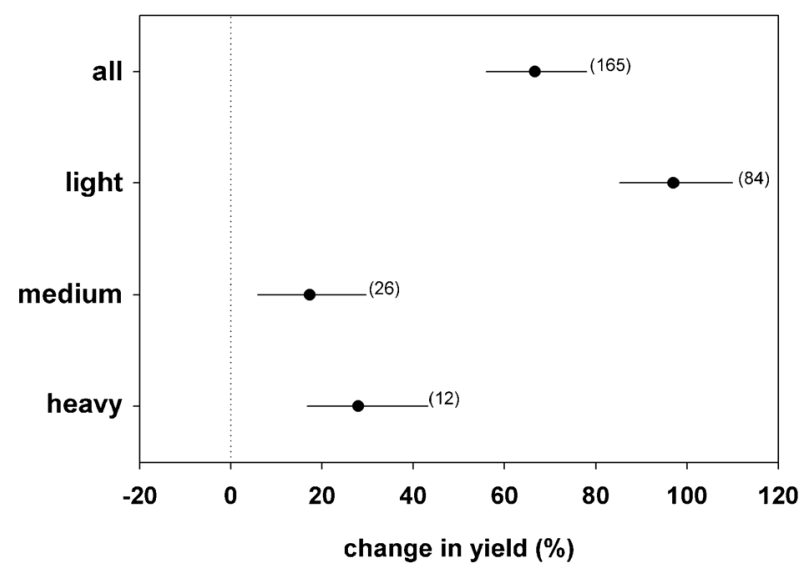

Fig. 6 Percent change in yield across nutrient amendment scenarios sorted by soil texture. Effect of nutrient amendment on sorghum yield in units of percent change from the control (no nutrient inputs) grouped by soil texture. Mean values and $95 \%$ confidence intervals of the backtransformed response ratios are shown (number of comparisons in parentheses) 
Additionally, for ecological studies, one is comparing outcomes across a broad gradient of environmental conditions.

Another limitation of meta-analysis is whether the data set is indicative of true population dynamics. We followed a standard meta-analysis practice of deriving data from peer-reviewed journal literature. As mentioned in section 2.2, this may result in some data sets being excluded from the analysis. However, an analysis of publication bias can illuminate whether the data are skewed, for instance, due to the absence of negative outcomes in the peer-reviewed literature. In this study, publication bias analysis suggested that negative data were published and that studies with greater replicates converged on the observed mean. Furthermore, once a critical mass of data is compiled, meta-analysis results are a good indication of population mean dynamics. Additional data points can narrow the confidence interval range of the analysis, but are not expected to significantly alter the mean effect size.

\subsection{Economic feasibility of management alternatives}

Access to $\mathrm{N}$ inputs is a serious limitation to cereal yield improvement in Africa. Edmonds et al. (2009) found that fertilizer use in sub-Saharan Africa has been declining in the beginning of the twenty-first century while population continues to increase. Increasing population and declining yields may lead to smaller per capita farm sizes and lower per capita incomes. This in turn may make it difficult for many African farmers to purchase inorganic fertilizer. Therefore, it is important to consider the benefits and costs of non-chemical input treatments such as legume rotation and OM amendments as possible alternatives to chemical fertilizer. Management using organic nutrient inputs is potentially more affordable to farmers and provides ecological services of improved soil fertility, increased soil water-holding capacity, and reduced soil compaction.

Our meta-analysis is a comprehensive analysis of field observations and provides a quantitative metric for how nutrient management techniques affect sorghum yield. After completing the meta-analysis, we applied the results of how sorghum yield responds to nutrient management with input and output prices to assess the profitability of these practices. Results from the profitability scenarios are presented in Tables 2, 3, 4 , and 5. Table 2 presents the yield and revenue increase for six different nutrient amendment scenarios applied to three focus countries across Africa. In order to better understand the distribution of the returns to various treatments, we assess country-specific yield response rates using the meta-analysis outcomes for (i) the mean, (ii) the lower $95 \%$ confidence interval, and (iii) the upper $95 \%$ confidence interval. Yields across treatments were highest in Burkina Faso, followed by Zimbabwe and Ethiopia. This order is generally reflective of relative agronomic conditions in these countries. Yield gain from a nutrient treatment follows the results from the metaanalysis (Fig. 4, Table 2), sorghum amended with $\mathrm{N}$ and $\mathrm{P}$ had the highest additional yield gain at the mean response, followed by manure amendment, then treatment with $\mathrm{N}$ only, followed by $\mathrm{N}$ and $\mathrm{P}$ microdosing, and finally sorghum under legume management. However, when considering the additional and net revenue of amendment treatments, the benefit of each treatment does not strictly follow the yield outcomes. Below we outline how combining an economic analysis to the ecological outcomes provides a different recommendation for farmers to maximize profitability.

Different findings emerge when examining the additional revenue from various management strategies. In Burkina Faso, $\mathrm{N}$ and $\mathrm{P}$ amendment generated the highest revenue when assuming a mean yield response; revenue from other treatments followed the ordering manure, legume rotation, $\mathrm{N}$ amendment, $\mathrm{N}$ and $\mathrm{P}$ microdose, and legume intercropping, in descending order (Table 2). In contrast, in Ethiopia and Zimbabwe, sorghum rotated with cowpea generated the highest revenue assuming a mean yield response, followed by $\mathrm{N}$ and $\mathrm{P}$ amendment, manure, $\mathrm{N}$ amendment, $\mathrm{N}$ and $\mathrm{P}$ microdose, and legume intercropping (Table 2). This is an important finding because cowpea is not widely grown in these countries. However, the value added from cowpea in terms of revenue and household nutritional benefits raises the potential for promoting sorghum and cowpea in rotation.

Table 3 presents median fertilizer application rate and cost for four nutrient amendment practices across the three focus countries in Africa; in addition, the cost of cowpea seed is considered under legume management. Fertilizer costs were calculated for the median $\mathrm{N}$ and $\mathrm{P}$ amendment rates derived from the meta-analysis. We focus on fertilizer costs because fertilizer is usually the limiting factor for many farmers in Africa. Additionally, the cost of sorghum seed would remain the same across the different nutrient amendment treatments, the only management difference compared is the nutrient amendment practice.

Labor is also a cost of production in these systems. Legume intercropping is generally regarded as having a higher labor cost associated with it than mono-cropping a single cereal (Kanyama-Phiri et al. 2000; Snapp et al. 2002). However, because farm labor in sub-Saharan Africa typically comes from the household directly, there is no standardization for quantifying labor costs. Even if we consider an additional per hectare labor cost of US $\$ 40$ for applying nutrient amendments compared to the control of no amendments, most of the amendments would still be profitable. Therefore, we find it more accurate to focus our cost assessment on purchased inputs.

Based on nutrient application rates and relevant prices, Table 3 shows $\mathrm{N}$ and $\mathrm{P}$ amendment had the highest cost per hectare across the three countries at the median application rate. This was not surprising given the relatively large quantity of $\mathrm{N}$ and $\mathrm{P}$ applied (Table 3) to achieve the mean yield increase observed in the meta-analysis (Table 2, Fig. 4). 
Table 2 Yield and revenue increase by country across nutrient amendment treatments

\begin{tabular}{|c|c|c|c|c|c|c|c|c|c|}
\hline & \multicolumn{3}{|c|}{ Mean yield increase } & \multicolumn{3}{|c|}{ Yield increase at lower $95 \% \mathrm{CI}^{*}$} & \multicolumn{3}{|c|}{ Yield increase at upper $95 \% \mathrm{CI}$} \\
\hline & $\begin{array}{l}\text { Burkina } \\
\text { Faso }\end{array}$ & Ethiopia & Zimbabwe & $\begin{array}{l}\text { Burkina } \\
\text { Faso }\end{array}$ & Ethiopia & Zimbabwe & $\begin{array}{l}\text { Burkina } \\
\text { Faso }\end{array}$ & Ethiopia & Zimbabwe \\
\hline \multicolumn{10}{|l|}{ Yield $^{\mathrm{a}}$ increase in $\mathrm{kg} \mathrm{ha}^{-1}$ (treatment-control) } \\
\hline Nitrogen only & 720 & 390 & 580 & 550 & 300 & 440 & 930 & 510 & 740 \\
\hline Nitrogen and Phosphorus & 990 & 540 & 790 & 720 & 390 & 580 & 1300 & 710 & 1030 \\
\hline NPK microdose & 470 & 260 & 380 & 320 & 170 & 250 & 650 & 350 & 520 \\
\hline Sorghum-cowpea intercropping (1 ha sorghum) & 440 & 240 & 350 & 250 & 140 & 200 & 630 & 340 & 500 \\
\hline Sorghum-cowpea rotation $^{\mathrm{b}}$ ( 0.5 ha sorghum) & 220 & 120 & 175 & 125 & 70 & 100 & 315 & 170 & 250 \\
\hline Sorghum-cowpea rotation $^{\mathrm{c}}(0.5$ ha cowpea $)$ & 410 & 410 & 410 & 410 & 410 & 410 & 410 & 410 & 410 \\
\hline Manure & 880 & 480 & 700 & 610 & 330 & 490 & 1170 & 640 & 930 \\
\hline \multicolumn{10}{|l|}{ Grain price (US $\$ \mathrm{~kg}^{-1}$ ) } \\
\hline Sorghum $^{\mathrm{d}}$ & $\$ 0.20$ & $\$ 0.30$ & $\$ 0.19$ & $\$ 0.20$ & $\$ 0.30$ & $\$ 0.19$ & $\$ 0.20$ & $\$ 0.30$ & $\$ 0.19$ \\
\hline Cowpea $^{\mathrm{e}}$ & $\$ 0.28$ & $\$ 0.54$ & $\$ 0.59$ & $\$ 0.28$ & $\$ 0.54$ & $\$ 0.59$ & $\$ 0.28$ & $\$ 0.54$ & $\$ 0.59$ \\
\hline \multicolumn{10}{|c|}{ Additional revenue ${ }^{\mathrm{f}}$ per hectare from treatment (yield increase $*$ price) } \\
\hline Nitrogen only & $\$ 144$ & $\$ 117$ & $\$ 110$ & $\$ 110$ & $\$ 90$ & $\$ 84$ & $\$ 186$ & $\$ 153$ & $\$ 141$ \\
\hline Nitrogen and phosphorus & $\$ 198$ & $\$ 162$ & $\$ 150$ & $\$ 144$ & $\$ 117$ & $\$ 110$ & $\$ 260$ & $\$ 213$ & $\$ 196$ \\
\hline NPK microdose & $\$ 94$ & $\$ 78$ & $\$ 72$ & $\$ 64$ & $\$ 51$ & $\$ 48$ & $\$ 130$ & $\$ 105$ & $\$ 99$ \\
\hline Sorghum-cowpea intercropping & $\$ 88$ & $\$ 72$ & $\$ 67$ & $\$ 50$ & $\$ 42$ & $\$ 38$ & $\$ 126$ & $\$ 102$ & $\$ 95$ \\
\hline Sorghum-cowpea rotation & $\$ 159$ & $\$ 257$ & $\$ 275$ & $\$ 140$ & $\$ 242$ & $\$ 261$ & $\$ 178$ & $\$ 272$ & $\$ 289$ \\
\hline Manure & $\$ 176$ & $\$ 144$ & $\$ 133$ & $\$ 122$ & $\$ 99$ & $\$ 93$ & $\$ 234$ & $\$ 192$ & $\$ 177$ \\
\hline
\end{tabular}

*CI Confidence Interval

${ }^{\text {a }}$ Yield values are from the meta-analysis and are rounded to nearest $10 \mathrm{~kg}$

${ }^{\mathrm{b}}$ The sorghum-cowpea rotation assumes 0.5 ha planted to sorghum, 0.5 ha planted to cowpea

${ }^{\mathrm{c}}$ Cowpea rotations are unfertilized and cowpea yields are assigned as $820 \mathrm{~kg} \mathrm{ha}^{-1}$ based on Kaizzi et al. (2007)

${ }^{\mathrm{d}}$ Sorghum prices are 5-year average from FAOSTAT

${ }^{\text {e }}$ Cowpea prices are five year average from FAOSTAT, (due to availability cowpea prices for Zimbabwe come from Malawi)

${ }^{\mathrm{f}}$ Additional Revenue numbers rounded to the nearest US $\$ 1.00$

Nitrogen-only amendment generated the second highest cost per hectare, while NPK microdose amendment generated a smaller cost per hectare than applying only $\mathrm{N}$, due to the targeted nature of the fertilizer application. Because we calculated costs using the median field application rate of fertilizer, these costs are a realistic estimate of farmer costs. Given the high variation in experimental application rates under the $\mathrm{N}$ and $\mathrm{P}$ treatment, our revenue and costs analysis is an optimistic assessment of farmer costs to achieve the doubling of yield observed in the $\mathrm{N}$ and $\mathrm{P}$ treatment in this meta-analysis. Nutrient amendment through management of legume intercropping or legume in rotation with sorghum had a fertilizer cost per hectare of zero because fertilizer was not used, with all $\mathrm{N}$ added to the system coming from $\mathrm{N}$ fixation during the cowpea growing season. The cost of legume seeds was similar to that of microdosing inputs.

Table 4 presents the net return per hectare of the four amendments based on median fertilizer application rates. These results make the assumption that households have access to different types of fertilizer and the resources to purchase them. While this assumption may not necessarily be realistic for many farmers in Africa, the results illustrate the economic potential of sorghum using different amendments if the constraints to fertilizer use can be overcome.

Table 4 demonstrates that $\mathrm{N}$ amendment through management of cowpea in rotation with sorghum generated the highest return for all countries studied. This was clearly due to the high revenue generated from planting half a hectare to cowpea and the zero cost of fertilizer. Legume intercropping also generated favorable revenue, though significantly less than the sorghum-cowpea rotation because cowpea is not sold in this scenario. The potential for legume intercropping to significantly increase agroecosystem profitability was similarly concluded in a local assessment of conventional maize compared with maize-pigeonpea intercropping in Malawi (Ngwira et al. 2012). In this system, the net return of the maize-pigeonpea system was double than that of the conventional maize system. These results point to the value of including a legume in the rotation with sorghum. 
Table 3 Management costs

\begin{tabular}{|c|c|c|c|}
\hline & Burkina Faso & Ethiopia & Zimbabwe \\
\hline \multicolumn{4}{|l|}{ Median fertilizer application rate ${ }^{\mathrm{a}}\left(\mathrm{kg} \mathrm{ha}^{-1}\right)$} \\
\hline Nitrogen only (urea or $\mathrm{NH}_{4} \mathrm{NO}_{3}$ ) & 64 & 64 & 86 \\
\hline Nitrogen and phosphorus (NPK or DAP) ${ }^{b}$ & 54 urea + 133 NPK & 58 urea +85 DAP & $100 \mathrm{NH}_{4} \mathrm{NO}_{3}+143 \mathrm{NPK}$ \\
\hline NPK microdose & 23 & 16 & $5 \mathrm{NH}_{4} \mathrm{NO}_{3}+23 \mathrm{NPK}$ \\
\hline Cowpea (intercropping or rotation) & 0 & 0 & 0 \\
\hline \multicolumn{4}{|l|}{ Fertilizer price $^{\mathrm{c}}$ (US $\$ \mathrm{~kg}^{-} 1$ ) } \\
\hline Nitrogen only (urea or $\mathrm{NH}_{4} \mathrm{NO}_{3}$ ) & $\$ 0.76$ & $\$ 0.69$ & $\$ 0.84$ \\
\hline Nitrogen and phosphorus (NPK or DAP) & $\$ 0.58$ & $\$ 0.86$ & $\$ 0.75$ \\
\hline \multicolumn{4}{|l|}{ Fertilizer cost per hectare (US \$) } \\
\hline Nitrogen only (urea or $\mathrm{NH}_{4} \mathrm{NO}_{3}$ ) & $\$ 48.64$ & $\$ 44.16$ & $\$ 72.24$ \\
\hline Nitrogen and phosphorus (NPK or DAP) & $\$ 118.18$ & $\$ 113.12$ & $\$ 191.25$ \\
\hline NPK microdose & $\$ 13.34$ & $\$ 13.76$ & $\$ 21.45$ \\
\hline Cowpea (intercropping or rotation) & $\$ 0.00$ & $\$ 0.00$ & $\$ 0.00$ \\
\hline \multicolumn{4}{|l|}{ Legume seed cost ${ }^{\mathrm{d}}$ (US \$ kg) } \\
\hline Cowpea & $\$ 1.00$ & $\$ 1.00$ & $\$ 1.00$ \\
\hline \multicolumn{4}{|l|}{ Legume management cost per hectare ${ }^{\mathrm{e}}$ (US \$) } \\
\hline Cowpea (intercropping or rotation) & $\$ 12.50$ & $\$ 12.50$ & $\$ 12.50$ \\
\hline
\end{tabular}

The median fertilizer application rate and cost by country across amendment treatments and the cost of legume management are presented. Manure amendment was not included in this table because reliable application rates and cost information are not available

${ }^{a}$ Application rates are derived from the meta-analysis

${ }^{\mathrm{b}}$ NPK combination is 15-15-15 in Burkina Faso, DAP in Ethiopia, and Compound D 7-14-7 in Zimbabwe

${ }^{\mathrm{c}}$ Fertilizer price data are from AfricaFertilizer.org and household surveys, calculated as median price per kilogram

${ }^{\mathrm{d}}$ Cost of seeds derived from Coulibaly (2008)

${ }^{\mathrm{e}}$ Legume management derived from Dugje et al. (2009)

There are several key points to consider with this finding. First, legumes such as cowpea can often be used as a cash crop to provide income for households. Second, legumes provide nutritional benefits as an important source of protein when consumed by households. Third, legumes return nitrogen to the soil, which over time can lessen the need to apply inorganic $\mathrm{N}$ fertilizers. Fourth, sorghum-cowpea intercropping is a traditional rotation in many regions of East Africa and can reduce Striga pest pressure (Carsky et al. 2010). Additionally, adding a legume to a rotation is the only management technique that adds $\mathrm{N}$ to the system using solar energy rather than fossil fuel energy. Fertilizer production is an energy intensive process and even in highly mechanized agricultural systems of the US Corn Belt, energy resulting from fertilizer production is $>30 \%$ of farm energy use in rain-fed maize systems (Kim et al. 2009). Assuming a cowpea seed yield of $820 \mathrm{~kg} \mathrm{ha}^{-1}$ (Kaizzi et al. 2007) and seed $\mathrm{N}$ content of $4 \%$ (Tagoe et al. 2010), sale of cowpea seed removes $16.4 \mathrm{~kg} \mathrm{~N} h a^{-1}$ of the $\mathrm{N}$ fixed during the

Table 4 Net return per ha (revenue - amendment cost) at median fertilizer application rate

\begin{tabular}{|c|c|c|c|c|c|c|c|c|c|}
\hline \multirow[t]{2}{*}{ Treatment } & \multicolumn{3}{|c|}{ With mean yield improvement } & \multicolumn{3}{|c|}{$\begin{array}{l}\text { With yield improvement at lower } \\
95 \% \text { CI }\end{array}$} & \multicolumn{3}{|c|}{$\begin{array}{l}\text { With yield improvement at upper } \\
95 \% \text { CI }\end{array}$} \\
\hline & Burkina Faso & Ethiopia & Zimbabwe & $\begin{array}{l}\text { Burkina } \\
\text { Faso }\end{array}$ & Ethiopia & Zimbabwe & $\begin{array}{l}\text { Burkina } \\
\text { Faso }\end{array}$ & Ethiopia & Zimbabwe \\
\hline Nitrogen only (urea or $\mathrm{NH}_{4} \mathrm{NO}_{3}$ ) & $\$ 95$ & $\$ 73$ & $\$ 38$ & $\$ 61$ & $\$ 46$ & $\$ 11$ & $\$ 137$ & $\$ 109$ & $\$ 68$ \\
\hline Nitrogen and phosphorus (NPK or DAP) & $\$ 80$ & $\$ 49$ & $-\$ 41$ & $\$ 26$ & $\$ 4$ & $-\$ 81$ & $\$ 142$ & $\$ 100$ & $\$ 4$ \\
\hline NPK microdose & $\$ 81$ & $\$ 64$ & $\$ 51$ & $\$ 51$ & $\$ 37$ & $\$ 26$ & $\$ 117$ & $\$ 91$ & $\$ 77$ \\
\hline Legume intercropping & $\$ 76$ & $\$ 60$ & $\$ 54$ & $\$ 38$ & $\$ 30$ & $\$ 26$ & $\$ 114$ & $\$ 90$ & $\$ 83$ \\
\hline Legume rotation (sorghum and cowpea) & $\$ 146$ & $\$ 245$ & $\$ 263$ & $\$ 127$ & $\$ 230$ & $\$ 248$ & $\$ 165$ & $\$ 260$ & $\$ 277$ \\
\hline
\end{tabular}

Net revenue numbers are rounded to the nearest US \$1.00. Italics indicate management incurs a net loss

CI Confidence Interval 
Table 5 Sensitivity analysis: break-even cost of fertilizer based on estimated yield improvements and grain prices from Tables 2, 3, and 4

\begin{tabular}{|c|c|c|c|c|c|c|c|c|c|}
\hline \multirow[t]{2}{*}{ Treatment } & \multicolumn{3}{|c|}{ With mean yield improvement } & \multicolumn{3}{|c|}{$\begin{array}{l}\text { With yield improvement at lower } \\
95 \% \text { CI }\end{array}$} & \multicolumn{3}{|c|}{$\begin{array}{l}\text { With yield improvement at upper } \\
95 \% \text { CI }\end{array}$} \\
\hline & Burkina Faso & Ethiopia & Zimbabwe & $\begin{array}{l}\text { Burkina } \\
\text { Faso }\end{array}$ & Ethiopia & Zimbabwe & $\begin{array}{l}\text { Burkina } \\
\text { Faso }\end{array}$ & Ethiopia & Zimbabwe \\
\hline Nitrogen only (urea or $\mathrm{NH}_{4} \mathrm{NO}_{3}$ ) & $\$ 2.25$ & $\$ 1.83$ & $\$ 1.28$ & $\$ 1.72$ & $\$ 1.41$ & $\$ 0.97$ & $\$ 2.91$ & $\$ 2.39$ & $\$ 1.63$ \\
\hline Nitrogen and phosphorus (NPK or DAP) & $\$ 1.18$ & $\$ 1.44$ & $\$ 0.46$ & $\$ 0.77$ & $\$ 0.91$ & $\$ 0.18$ & $\$ 1.65$ & $\$ 2.04$ & $\$ 0.78$ \\
\hline NPK microdose & $\$ 4.09$ & $\$ 4.88$ & $\$ 2.96$ & $\$ 2.78$ & $\$ 3.19$ & $\$ 1.88$ & $\$ 5.65$ & $\$ 6.56$ & $\$ 4.11$ \\
\hline
\end{tabular}

Italics indicate break even price occurs following a reduction in current fertilizer price

CI Confidence Interval

legume growing season (given our legume management scenarios which assume 0.5 ha of legume per growing season). Based on observed $\mathrm{N}$ fixation in African cowpea varieties ranging from 48-182 $\mathrm{kg} \mathrm{N} \mathrm{ha}^{-1}$ (Belane et al. 2014), the remaining root and shoot biomass would provide on the order of 7$75 \mathrm{~kg} \mathrm{~N} \mathrm{ha}{ }^{-1}$ to the field or for use as animal fodder.

The benefits of legumes in rotation need to be qualified; however, because they assume that farmers have access to cowpea seeds, can generate a significant return when planting cowpea, and have a place to market cowpea; this may be a large assumption for many farmers in Africa. Kerr et al. (2007) discussed uncertain market access, unstable legume prices, limited access to improved seeds, and insufficient research attention to multi-functional benefits of legumes as barriers to legume adoption. In their participatory research study of legume adoption in Malawi, Kerr et al. (2007) identified addressing soil nutrient deficiencies using more cost-effective technologies than fertilizer as a high priority for farmers. Kerr et al. (2007) documented increased farmer interest in legumes with farmer participation increasing from 183 individuals to over 3000 individuals in 4 years. Additionally, many farmers indicated that they successfully substituted legumes as an alternative to fertilizer application. Though farmers face challenges to incorporating legumes in a rotation, our results illustrate the potential benefits to including a legume such as cowpea in rotation with sorghum.

Across the inorganic nutrient amendment scenarios at a mean yield response, $\mathrm{N}$-only amendment had the highest net return in Burkina Faso and Ethiopia, while NPK microdose amendment was most profitable in Zimbabwe. The returns to microdosing and N-only amendment are positive across all countries. The relatively high return to NPK microdose comes from the low level of fertilizer that needs to be applied in order to achieve the observed mean yields. The fact that microdosing targets fertilizer close to the root system of the plant cuts down on the amount that needs to be applied. This can be useful for farmers who are only able to purchase fertilizer in small quantities, due to income or credit constraints. The drawback to microdosing is that it is labor intensive compared to other forms of application, so may not be realistic for households who have limited family labor available and are unable to hire in labor from outside.
Regardless, it is worth training farmers on the potential of microdosing, particularly in areas where fertilizer access and use is limited.

Amendment with $\mathrm{N}$ and $\mathrm{P}$ produced the lowest return among the four amendment scenarios for Ethiopia and Zimbabwe, and there was a net loss in Zimbabwe. In contrast, in high-yielding Burkina Faso, the $\mathrm{N}$ and $\mathrm{P}$ amendment had a favorable net return. Given the relatively high application rate of both urea and NPK that is needed to generate the mean yield increase in Table 2, the returns to $\mathrm{N}$ and $\mathrm{P}$ amendment were not favorable in regions with moderate to low sorghum yield. While fertilizer application is often the focus of discussion surrounding increasing grain yield in Africa (e.g., Mueller et al. 2012), this analysis of field data coupled to an economic assessment suggest that fertilizer application is not always a profitable scenario for smallholder farmers. Rather, optimal management will depend on regional environmental and market conditions.

Manure amendment showed great potential to increase yields and generate revenue for farmers across the three focus countries in this study. The costs and net profitability of manure were not calculated in Tables 3 and 4 because reliable application rates and cost information were not available and an agronomic and economic survey of manure use in households is beyond the scope of this research. Nevertheless, the positive returns in Table 2 suggest that it is worth considering wider promotion of animal manure. This is particularly the case in places like Ethiopia and Zimbabwe where livestock agriculture is widespread and farmers have access to animal manure. In places where livestock is less common programs that promote livestock rearing can have the double benefit of increasing incomes through livestock meat and products and increasing efficient use of nutrients through manure application to cropping systems. Increased use of manure also offers farmers a sustainable solution when credit constraints inhibit them from purchasing inorganic fertilizer on the commercial market. In addition, manure can be sourced locally compared to inorganic fertilizer which must be imported into much of subSaharan Africa at a high cost.

Part of the challenge in pricing manure management is that designing optimal manure management is complex and dependent on site properties. In a study of manure application 
in Zimbabwe, Zingore et al. (2008) demonstrated that the benefits of fertilizer or manure application depend on soil texture and nutrient management history. Compared to clayey soils, sandy soils accrued greater benefit from manure application as manure increased micronutrient availability and reduced nutrient leaching, both more prominent problems in sandy soils. Zingore et al. (2008) also discussed that simply adding inorganic fertilizer in African systems with poor fertility, especially low SOC, was not a long-term successful management strategy due to reduction in soil $\mathrm{pH}$ and insufficient focus on managing micronutrients, especially calcium. However, it is important to note that adding manure to soil can complement inorganic fertilizer, making it more effective at increasing yields through build up of soil organic matter (SOM) and resulting increase in cation exchange capacity (CEC), nutrient retention, and $\mathrm{pH}$ (Zingore et al. 2008). After 9 years of manure application in this Zimbabwe system, Rusinamhodzi et al. (2013) reported long-term manure application resulted in improved soil fertility by increasing SOC content in both clayey and sandy soils. Increased SOC benefits crop productivity by improving moisture retention (especially in sandy soils), nutrient retention, and soil structure. Manure addition also improved yields by increasing water infiltration on clayey soils.

Though manure amendment has many benefits, manure application is not always readily practiced. Rusinamhodzi et al. (2013) assessed that farmer access to manure was only sufficient to supply a fraction of their landbase; therefore, farmers strategically use manure on home fields to reap the best yields. In a survey of smallholder manure usage in South Africa, Materechera (2010) identified lack of labor and transportation as limitations to manure management. Adoption of manure application practices was also limited due to reduced manure quality (resulting from poor storage facilities and technical knowledge), as well as farmer concern that manure application led to higher infestation with weeds, insects, and worms. While manure has many long-term soil improvement benefits, especially increased SOC, depending on storage prior to application, much of the manure $\mathrm{N}$ content can be lost through leaching or volatilization, making manure application insufficient for supplying total crop $\mathrm{N}$ needs.

Table 5 provides a sensitivity analysis for the fertilizer price that allows farmers to break-even in Burkina Faso, Ethiopia, and Zimbabwe for each nutrient amendment. Since the price of inorganic fertilizer fluctuates across countries and over time, it is important to estimate a range of how much the price per kilogram of each nutrient amendment can increase (or decrease in a few scenarios) and still allow farmers to break-even (make zero profits). In order to give a realistic range and provide useful site specific information, we run the sensitivity analysis for the mean yield improvement along with the lower $95 \%$ confidence interval yield improvement and the upper $95 \%$ confidence interval yield improvement. The sensitivity analysis presented in Table 5 is itself a simplification because it assumes that farmers do not adjust input use as input prices change. Nevertheless, the results of Table 5 demonstrate that given the yield increases from different amendment strategies found in this meta-analysis, many of the amendments will remain profitable with fairly substantial increases in fertilizer prices, and no change in input use.

\subsection{Contextual agricultural development}

Our analysis focused on the role of nutrient amendment in supporting crop yield and farmer profit. In addition to promoting access to nutrient amendments, agricultural development must consider ecological needs regarding pest management and uncertainty from climate change, as well as farmer socioeconomic and cultural needs.

Pests such as Striga and stem borers can have devastating consequences for grain yield throughout Africa. In addition to herbicide application (Carsky et al. 1994; Tuinstra et al. 2009) and the use of fungal spores (Marley and Shebayan 2005; Venne et al. 2009), crop rotation has been demonstrated to control Striga and improve yield. Carsky et al. (2010) demonstrated maize-soybean rotations reduced the Striga-derived yield decline in maize relative to a continuous grain rotation; the authors suggest the control mechanism is soybean reduction of the Striga viable seedbank by exuding a germination stimulant. De Groote et al. (2010) and Khan et al. (2008) compared yield and profit across maize monoculture and push-pull rotations for Striga and stem borer control, including rotations with green manures. Cropping system complexity was demonstrated to improve grain yield and cropping system profitability. Kfir et al. (2002) identified intercropping, crop residue management, and manipulation of sowing dates and densities as successful measures against stem borer infestation. Nutrient amendment which diversifies crop rotation or promotes incorporation of plant residues has the potential for co-benefits with regard to pest management. A 20-year study of Striga control (Ayongwa et al. 2010) showed infestation increased across sorghum and maize crops. However, the study also showed that the level of Striga infestation did not strongly correlate to yield decline. Instead, the impact of Striga infestation appeared to be compounded by poor soil fertility. Over the study period, pressure to increase yields reduced fallow periods and increased cereal mono-cropping, both of which facilitate Striga infestation. These studies demonstrate that management strategies must consider the multi-dimensional challenges to sorghum yield improvement.

A systems approach to managing agricultural landscapes aims to improve field conditions for multiple environmental drivers of crop growth and is often focused on improving crop yield by supporting biological processes in the rhizosphere. Integrated Soil Fertility Management (ISFM) embraces a systems approach and is widely adopted as a driving philosophy in the African Green Revolution (Vanlauwe et al. 2012; Vanlauwe 2013). Crop residue management and diversified rotations are two main techniques for promoting rhizosphere 
processes. For example, crop residue management improved cereal growth in Sahel regions by increasing $\mathrm{P}$ availability, increasing root growth, decreasing soil erosion, and improving OM retention (Buerkert et al. 2000). Use of cereal-legume rotations changed soil biological and chemical properties relative to soils in continuous grain rotations, in particular, promoting increased mycorrhizal infection rates and increased $\mathrm{P}$ access (Alvey et al. 2001). Strategic use of N-fixing tree species can also improve plant nutrient access and crop yield (e.g., Payne et al. 1998; Wilson et al. 1998). A recent review by Bayala et al. (2012) quantified the yield impact of various conservation agriculture techniques, demonstrating a significant sorghum yield improvement under management including green manure, diversified rotations, and mulching. Strategic crop diversification and residue management can improve biological, chemical, and physical rhizosphere properties resulting in improved plant access to nutrients.

Adoption of innovations against vulnerability is a key strategy for climate resilience in drought-susceptible Sahelian regions and the need for water management is magnified by soil degradation (Barbier et al. 2009; Stroosnijder 2009). A review of crop models by Kang et al. (2009) emphasized that crop yield can decline due to water stress from reduced precipitation as well as increased evapotranspiration resulting from increased temperature. A variety of water management strategies are available to African farmers. Improved plant available moisture was observed under OM amendment, hedgerow, and stone row management (Stroosnijder 2009), as well as under intercropping (Oluwasemire et al. 2002). Conservation agriculture techniques - including residue management, diversified rotations, and reduce tillage - have demonstrated the potential to improve soil nutrient and moisture availability, and ultimately improve crop growth when management is appropriately designed for field environmental conditions (e.g., Rusinamhodzi et al. 2011; Siddique et al. 2012; Thierfelder et al. 2012, 2013; Thierfelder and Wall 2009). Recent work by Traore et al. (2014) identified how grain crop varieties and planting dates can be selected to optimize yield under variable rainfall patterns and access to fertilizer. These studies demonstrate that nutrient management and improved water use efficiency are complementary goals to buffer agricultural productivity against climate and population pressure on the agricultural land base.

Work by Jones and Thornton (2009) emphasized that enhancing food security will include livelihood transitions in addition to improved crop productivity. Their analysis of downscaled climate predictions for sub-Saharan Africa identified regions where increased likelihood of cropping failures should be buffered by increasing the dependence on livestock farming. Using farmer surveys to analyze farmer response to climate variables, Seo (2010) similarly concluded that higher diversity in farm management is a likely response to mitigating climate change risk. Multiple studies suggest that increased farm diversity is an important component of reducing farmer risk to environmental variation and resource constraints (e.g., Rufino et al. 2006; Valbuena et al. 2012), implying that opportunities for farmers to include diverse rotations and manure management as nutrient amendment strategies are important components of sustainable agricultural management.

This meta-analysis suggests adding legumes to a sorghum rotation can be profitable and ecologically beneficial for farmers; however, this recommendation needs to be viewed in light of farmer interests outlined in participatory research. For instance, Snapp et al. (2002) found farmers in Malawi identified maize-legume rotations as having advantages including less labor and land for two crops, easier weed control, increased food security, fuelwood production, improved soil fertility, and cash sales potential. However, farmers also experienced challenges implementing these diversified rotations including seed availability, slow legume growth or late harvest, livestock damage, low grain legume price, and limited market access. In a national-scale study of the potential of diversified systems in Malawi, Snapp et al. (2010) highlighted the need to choose appropriate legumes when developing diversified cropping systems, in particular, legumes that perform well on degraded soils and have economic or livelihood value for the farmer. In this Malawi study, farmers preferred legume systems to maize monoculture, including short-duration grain legumes (peanut or soybean), intercropping (maizepigeonpea), and semi-perennial systems of maize-Mucuna pruriens, with the strongest preference for the $M$. pruriens system (despite its less palatable biomass, M. pruriens growth form has minimal interference with maize crop growth and produces abundant biomass). This participatory research demonstrated that developing cropping systems that are ecologically beneficial as well as socio-economically useful requires a significant engagement with stakeholder communities to assess farmers' cultural and economic needs.

\section{Conclusions}

We conducted a comprehensive review of sorghum response to different nutrient amendment scenarios in sub-Saharan Africa using meta-analysis (a robust quantitative tool for synthesizing compiled experiments to summarize aggregate trends). Our study synthesizes data representing a range of environmental conditions as well as a range of management options available to farmers. In addition, we combined these ecological outcomes with economic examples of how management costs, revenues, and net profits differ given recent prices for farm inputs and grain sales. We demonstrated that nutrient amendments generate significant yield improvements for sorghum cropping systems across sub-Saharan Africa, with yield improvements ranging from a 45 to $100 \%$ increase in yield relative to no nutrient inputs. 
Our analysis demonstrated increased sorghum yields when farmers apply inorganic fertilizer. Furthermore, inorganic fertilizer inputs using microdosing management techniques were demonstrated to have a significant financial advantage in an environment where sufficient labor is available. These results are in general agreement with the rationale for the 2006 Abuja Declaration, where many African governments committed to helping smallholder farmers increase the use of inorganic fertilizer, mainly through subsidizing the price of the input. As a result, fertilizer use has increased among smallholders in a number of African countries over the past few years, particularly for maize cultivation (Sheahan and Barrett 2014). However, while fertilizer use has increased, yields and response rates among African smallholders remain low, raising questions about the cost-effectiveness of providing subsidies for inputs (Jayne and Rashid 2013).

Various studies suggest that limiting agricultural management to focus only on inorganic fertilizer is insufficient to improve long-term yields on degraded soils (e.g., Jayne and Rashid 2013; Rusinamhodzi et al. 2013; Zingore et al. 2008). Our results highlighted that yields can also be improved by adding manure to soil or adding legumes in rotation, and for some cases, legume management was a particularly profitable scenario. Legume rotation also provides a source of proteinrich grain, improves soil nutrients reducing the need for inorganic $\mathrm{N}$ fertilizer over time, and has been demonstrated to control Striga infestation. The benefits of including a legume in rotation - which extend beyond improvement in grain yield - suggest the need for a systemic evaluation of how agricultural management strategies can improve farmer livelihoods. Our results and the systemic agricultural intensification concept of management support the ISFM strategy for improving yield and farmer livelihoods that is currently being promoted by The Alliance for a Green Revolution in Africa (AGRA).

While we demonstrated in this study that multiple nutrient amendment tools significantly improve sorghum yield, the appropriate nutrient strategy depends on (1) farmers' access to fertilizer, manure, seeds, labor, and credit; (2) the need for households to produce nutritionally balanced foods on-farm; (3) the extent of soil degradation: (4) the need to coordinate nutrient amendment with pest management strategies; and (5) farmers' increasing need to manage for climate change and other environmental risks. Due to its adaptation to African climatic patterns, especially tolerance of climatic extremes including drought and water-logged soils, sorghum is an important grain to consider for reducing risk under climatic uncertainty. This interdisciplinary analysis indicates potential benefits of supporting research and extension outreach to farmers that includes a broad range of sorghum management practices to simultaneously promote farm productivity and profitability.
Acknowledgements The authors thank Dr. Eric Lichtfouse and anonymous reviewers for their thorough and thoughtful comments that improved this manuscript.

\section{References}

Africa Fertilizer Database (2012) Available at http://www.africafertilizer.org/ Aguado-Santacruz GA, Moreno-Gómez B, Gómez-Torres LM, AnayaLópez JL (2012) Biotechnology of sorghum: prospects for improvement of nutritional and biofuel traits. In: Vázquez M, Ramírez de León JA (eds) Food energy source. Nova Science Publishers, pp $113-151$

Alvey S, Bagayoko M, Neumann G, Buerkert A (2001) Cereal/legume rotations affect chemical properties and biological activities in two West African soils. Plant Soil 231:45-54

Aune JB, Ousman A (2011) Effect of seed priming and micro-dosing of fertilizer on sorghum and pearl millet in Western Sudan. Exp Agric 47:419-430. doi:10.1017/S0014479711000056

Aune JB, Doumbia M, Berthe A (2007) Microfertilizing sorghum and pearl millet in Mali: agronomic, economic and social feasibility. Outlook Agric 36:199-203. doi:10.5367/000000007781891504

Ayongwa GC, Stomph TJ, Hoevers R et al (2010) Striga infestation in northern Cameroon: magnitude, dynamics and implications for management. NJAS Wagening J Life Sci 57:159-165. doi:10. 1016/j.njas.2010.04.003

Bado B V, Bationo A, Cescas MP, Sedogo MP (2007) Mineral fertilizers, organic amendments and crop rotation managements for soil fertility maintenance in the Guinean zone of Burkina Faso (West Africa). Adv Integr Soil Fertil Manag Sub-Saharan Africa Chall Oppor 171177

Bagayoko M, Buerkert A, Lung G et al (2000) Cereal/legume rotation effects on cereal growth in Sudano-Sahelian West Africa: soil mineral nitrogen, mycorrhizae and nematodes. Plant Soil 218:103-116

Barbier B, Yacouba H, Karambiri H et al (2009) Human vulnerability to climate variability in the Sahel: farmers' adaptation strategies in northern Burkina Faso. Environ Manag 43:790-803. doi:10.1007/ s00267-008-9237-9

Bationo A, Ayuk E, Ballo D, Kone M (1997) Agronomic and economic evaluation of Tilemsi phosphate rock in different agroecological zones of Mali. Nutr Cycl Agroecosyst 48:179-189

Bayala J, Sileshi GW, Coe R et al (2012) Cereal yield response to conservation agriculture practices in drylands of West Africa: a quantitative synthesis. J Arid Environ 78:13-25. doi:10.1016/j.jaridenv. 2011.10.011

Belane AK, Pule-Meulenberg F, Makhubedu TI, Dakora FD (2014) Nitrogen fixation and symbiosis-induced accumulation of mineral nutrients by cowpea (Vigna unguiculata L. Walp.). Crop Pasture Sci 65:250-258. doi:10.1071/CP13283

Boko M, Niang I, Nyong A et al. (2007) Africa. In: Parry ML, Canziani OF, Palutikof JP et al (eds) Impacts, Adapt. Vulnerability. Contrib. Work. Gr. II to Fourth Assess. Rep. Intergov. Panel Clim. Chang. pp 433-467

Bosede AJ (2010) Economic assessment of fertilizer use and integrated practices for environmental sustainability and agricultural productivity in Sudan savannah zone, Nigeria. Afr J Agric Res 5:338-343

Bostick WM, Bado VB, Bationo A et al (2007) Soil carbon dynamics and crop residue yields of cropping systems in the Northern Guinea Savanna of Burkina Faso. Soil Tillage Res 93:138-151. doi:10.1016/j.still.2006.03.020

Bremner J (2012) Population and food security: Africa's challenge. Population Reference Bureau, Policy Brief. <http://www.prb.org/ pdf12/population-foodsecurity-africa.pdf $>$ 
Buerkert A, Bationo A, Dossa K (2000) Mechanisms of residue mulchinduced cereal growth increases in West Africa 1 '. Soil Sci Soc Am J 64:346-358

Carsky RJ, Singh L, Ndikawa R (1994) Effect of herbicide and handweeding on current and subsequent season Striga hermonthica density on sorghum. Int J Pest Manag 40:111-116

Carsky RJ, Ndikawa R, Singh L, Rao MR (1995) Response of dry season sorghum to supplemental irrigation and fertilizer $\mathrm{N}$ and $\mathrm{P}$ on Vertisols in northern Cameroon. Agric Water Manag 28:1-8. doi: 10.1016/0378-3774(95)01169-J

Carsky RJ, Berner DK, Oyewole BD et al. (2010) International Journal of Pest Management Reduction of Striga hermonthica parasitism on maize using soybean rotation. 37-41

Chianu JN, Chianu JN, Mairura F (2012) Mineral fertilizers in the farming systems of sub-Saharan Africa. A review. Agron Sustain Dev 32:545-566. doi:10.1007/s13593-011-0050-0

Claussen M, Scheffran J, Brücher T (2015) Climate, land use, and conflict in Northern Africa. EOS Earth Space Sci News 96:8

Coe R, Stern RD (2011) Assessing and addressing climate-induced risk in sub-Saharan rainfed agriculture: lessons learned. Exp Agric 47:395410. doi:10.1017/S001447971100010X

Cooper PJM, Dimes J, Rao KPC et al (2008) Coping better with current climatic variability in the rain-fed farming systems of sub-Saharan Africa: an essential first step in adapting to future climate change? Agric Ecosyst Environ 126:24-35. doi:10.1016/j.agee.2008.01.007

Coulibaly O (2008) Baseline study for impact assessment of high quality insect resistant cowpea in West Africa

Croppenstedt A, Demeke M, Meschi M (2003) Technology adoption in the presence of constraints: the case of fertilizer demand in Ethiopia. Rev Dev Econ 7:58-70

De Groote H, Vanlauwe B, Rutto E et al (2010) Economic analysis of different options in integrated pest and soil fertility management in maize systems of Western Kenya. Agric Econ 41:471-482. doi:10.1111/j.1574-0862.2010.00459.x

Dicko MH, Gruppen H, Traoré AS et al (2006) Sorghum grain as human food in Africa: relevance of content of starch and amylase activities. 5:384-395

Dugje IY, Omoigui LO, Ekeleme F (2009) Farmers' guide to cowpea production in West Africa

Edmonds DE, Abreu SL, West A et al (2009) Cereal nitrogen use efficiency in sub Saharan Africa. J Plant Nutr 32:2107-2122

Ekeleme F, Kamara AY, Omoigui LO et al (2011) Effect of sowing date on Striga infestation and yield of sorghum (Sorghum bicolor [L.] Moench) cultivars in the Sudan savanna of northeast Nigeria. Afr J Agric Res 6:3240-3246

Elkhalifa AEO (2012) Fermented sorghum foods. In: Vázquez M, Ramírez de León JA (eds) Food energy source. Nova Science Publishers, pp 167-193

Ethiopian Rural Household Survey (ERHS) (2009) International Food Policy Research Institute, Washington DC. Available at http:// www.ifpri.org/dataset/ethiopian-rural-household-surveys-erhs

FAOSTAT (2012) Available at http://faostat3.fao.org/home/E

Farré I, Faci JM (2006) Comparative response of maize (Zea mays L.) and sorghum (Sorghum bicolor L. Moench) to deficit irrigation in a Mediterranean environment. Agric Water Manag 83:135-143. doi: 10.1016/j.agwat.2005.11.001

Flato G, Marotzke J, Abiodun B et al. (2013) Evaluation of climate models. Clim Chang 2013 Phys Sci Basis Contrib Work Gr I to Fifth Assess Rep Intergov Panel Clim Chang 741866. doi:10.1017/CBO9781107415324.020

Fox P, Rockström J (2000) Water-harvesting for supplementary irrigation of cereal crops to overcome intra-seasonal dry-spells in the Sahel. 25:289-296

Gurevitch J, Hedges LV (1999) Statistical issues in ecological meta-analyses. Ecology 80:1142-1149
Hagedorn F, Steiner KG, Sekayange L, Zech W (1997) Effect of rainfall pattern on nitrogen mineralization and leaching in a green manure experiment in South Rwanda. Plant Soil 195:365-375

Haile A, Hofsvang T (2001) Effect of sowing dates and fertilizer on the severity of stem borer (Busseola fusca Fuller, Lepidoptera: Noctuidae) on sorghum in Eritrea. Int J Pest Manag 47:259-264. doi:10.1080/09670870110046786

Hansen JW, Mason SJ, Sun L, Tall A (2011) Review of seasonal climate forecasting for agriculture in sub-Saharan Africa. Exp Agric 47: 205-240. doi:10.1017/S0014479710000876

Holloway G, Barrett C, Ehui S (2005) The double-hurdle model in the presence of fixed costs. J Int Agric Trade Dev 1:17-28

ICRISAT (2013) Sorghum macia impact assessment survey for Zimbabwe, Bulawayo

Jayne TS, Rashid S (2013) Input subsidy programs in sub-Saharan Africa: a synthesis of recent evidence. Agric Econ 44:547-562

Johnson DW, Curtis PS (2001) Effects of forest management on soil C and N storage: meta analysis. For Ecol Manag 140:227-238

Jones PG, Thornton PK (2009) Croppers to livestock keepers: livelihood transitions to 2050 in Africa due to climate change. Environ Sci Policy 12:427-437. doi:10.1016/j.envsci.2008.08.006

Kaizzi KC, Byalebeka J, Wortmann CS, Mamo M (2007) Low input approaches for soil fertility management in semiarid Eastern Uganda. Agron J 99:847-853. doi:10.2134/agronj2006.0238

Kang Y, Khan S, Ma X (2009) Climate change impacts on crop yield, crop water productivity and food security? A review. Prog Nat Sci 19:1665-1674. doi:10.1016/j.pnsc.2009.08.001

Kanyama-Phiri GY, Snapp S, Kamanga B, Wellard K (2000) Towards integrated soil fertility management in Malawi: incorporating participatory approaches in agricultural research. Manag. Africa's Soils 11

Kerr RB, Snapp S, Chirwa (deceased) M et al. (2007) Participatory research on legume diversification with Malawian smallholder farmers for improved human nutrition and soil fertility. Exp Agric 43:437-453. doi:10.1017/S0014479707005339

Kfir R, Overholt WA, Khan ZR, Polaszek A (2002) Biology and management of economically important lepidopteran cereal stem borers in Africa. Annu Rev Entomol 47:701-731. doi:10.1146/annurev. ento.47.091201.145254

Khan ZR, Midega CAO, Hassanali A et al (2007) Assessment of different legumes for the control of in maize and sorghum. Crop Sci 47:730 736. doi:10.2135/cropsci2006.07.0487

Khan ZR, Midega CAO, Njuguna EM et al (2008) Economic performance of the "push-pull" technology for stemborer and Striga control in smallholder farming systems in western Kenya. Crop Prot 27: 1084-1097. doi:10.1016/j.cropro.2008.01.005

Kim S, Dale BE, Jenkins R (2009) Life cycle assessment of corn grain and corn stover in the United States. Int J Life Cycle Assess 14:160 174

Knewtson SJB, Hons FM, Juo ASR, Hossner LR (2008) Cropping system effects and seasonal dynamics of extractable phosphorus in a Semi-arid soil of the Sahel, West Africa. Commun Soil Sci Plant Anal 39:217-230. doi:10.1080/00103620701759202

Knox J, Hess T, Daccache A, Wheeler T (2012) Climate change impacts on crop productivity in Africa and South Asia. Environ Res Lett 7: 034032. doi:10.1088/1748-9326/7/3/034032

Koricheva J, Gurevitch J (2014) Uses and misuses of meta-analysis in plant ecology. J Ecol 102:828-844. doi:10.1111/1365-2745.12224

Kouyat Z, Franzluebbers K, Juo ASR, Hossner LR (2000) Tillage, crop residue, legume rotation, and green manure effects on sorghum and millet yields in the semiarid tropics of Mali. Plant Soil 225:141-151

Liu J, Fritz S, van Wesenbeeck CFA et al (2008) A spatially explicit assessment of current and future hotspots of hunger in subSaharan Africa in the context of global change. Glob Planet Chang 64:222-235. doi:10.1016/j.gloplacha.2008.09.007

MacCarthy DS, Vlek PLG, Bationo A et al (2010) Modeling nutrient and water productivity of sorghum in smallholder farming 
systems in a semi-arid region of Ghana. Field Crop Res 118: 251-258. doi:10.1016/j.fcr.2010.06.005

Mafongoya PL, Bationo A, Kihara J, Waswa BS (2006) Appropriate technologies to replenish soil fertility in southern Africa. Nutr Cycl Agroecosyst 76:137-151. doi:10.1007/s10705-006-9049-3

Mando A, Ouattara B, Somado AE et al (2005) Long-term effects of fallow, tillage and manure application on soil organic matter and nitrogen fractions and on sorghum yield under Sudano-Sahelian conditions. Soil Use Manag 21:25-31. doi:10.1079/SUM2005287

Maranville JW, Pandey RK, Sirifi S (2002) Communications in soil science and plant analysis comparison of nitrogen use efficiency of a newly developed sorghum hybrid and two improved cultivars in the Sahel of West Africa. Commun Soil Sci Plant Anal 33:1519-1536

Marley PS, Shebayan JAY (2005) Field assessment of Fusarium oxysporum based mycoherbicide for control of Striga hermonthica in Nigeria. BioControl 50:389-399. doi:10.1007/s10526-004-0461-9

Materechera SA (2010) Utilization and management practices of animal manure for replenishing soil fertility among small-scale crop farmers in semi-arid farming districts of the north-west province, South Africa. Nutr Cycl Agroecosyst 87:415-423. doi:10.1007/s10705010-9347-7

Mueller ND, Gerber JS, Johnston M et al (2012) Closing yield gaps through nutrient and water management. Nature 490:254-257

Nakagawa S, Santos ESA (2012) Methodological issues and advances in biological meta-analysis. Evol Ecol 26:1253-1274. doi:10.1007/ s10682-012-9555-5

Ndiaye O, Ward MN, Thiaw WM (2011) Predictability of seasonal Sahel rainfall using GCMs and lead-time improvements through the use of a coupled model. J Clim 24:1931-1949. doi:10.1175/ 2010JCLI3557.1

Ngwira AR, Thierfelder C, Lambert DM (2012) Conservation agriculture systems for Malawian smallholder farmers: long-term effects on crop productivity, profitability and soil quality. Renew Agric Food Syst 28:1-14. doi:10.1017/S1742170512000257

Nyakatawa EZ, Maringa D, Murwira K (2001) Ridge-till effects on sorghum yields under organic and inorganic fertilizers in a semi-arid region of Zimbabwe. J Sustain Agric 17:53-65

Oluwasemire KO, Stigter CJ, Owonubi JJ, Jagtap SS (2002) Seasonal water use and water productivity of millet-based cropping systems in the Nigerian Sudan savanna near Kano. Agric Water Manag 56: 207-227. doi:10.1016/S0378-3774(02)00008-2

Ouédraogo E, Mando A, Zombré NP (2001) Use of compost to improve soil properties and crop productivity under low input agricultural system in West Africa. Agric Ecosyst Environ 84:259-266

Ouédraogo E, Brussaard L, Mando A, Stroosnijder L (2005) Organic resources and earthworms affect phosphorus availability to sorghum after phosphate rock addition in semi-arid West Africa. Biol Fertil Soils 41:458-465. doi:10.1007/s00374-005-0840-0

Ouédraogo E, Mando A, Brussaard L, Stroosnijder L (2007) Tillage and fertility management effects on soil organic matter and sorghum yield in semi-arid West Africa. Soil Tillage Res 94:64-74. doi:10.1016/j.still.2006.07.001

Pandey RK, Maranville JW, Bako Y (2007) Nitrogen fertilizer response and use efficiency for three cereal crops in Niger. Commun Soil Sci Plant Anal 32:1465-1482

Payne WA, Williams JH, Mai Moussa KA, Stern RD (1998) Crop diversification in the Sahel through use of environmental changes near Faidherbia albida (Del.) A. Chev Crop Sci 38:1585-1591

Philibert A, Loyce C, Makowski D (2012) Assessment of the quality of meta-analysis in agronomy. Agric Ecosyst Environ 148:72-82. doi: 10.1016/j.agee.2011.12.003

Ramirez-Villegas J, Challinor A (2012) Assessing relevant climate data for agricultural applications. Agric For Meteorol 161:2645. doi:10.1016/j.agrformet.2012.03.015
Ramirez-Villegas J, Jarvis A, Läderach P (2011) Empirical approaches for assessing impacts of climate change on agriculture: the EcoCrop model and a case study with grain sorghum. Agric For Meteorol. doi:10.1016/j.agrformet.2011.09.005

Reda F, Verkleij JAC, Ernst WHO (2005) Relay cropping of sorghum and legume shrubs for crop yield improvement and Striga control in the subsistence agriculture region of Tigray (Northern Ethiopia). J Agron Crop Sci 191:20-26

Rosenberg MS, Adams DC, Gurevitch J (2000) MetaWin statistical software for meta-analysis version 2.0

Roudier P, Sultan B, Quirion P, Berg A (2011) The impact of future climate change on West African crop yields: what does the recent literature say? Glob Environ Chang 21:1073-1083. doi:10.1016/j.gloenvcha.2011.04.007

Ruelland D, Ardoin-Bardin S, Collet L, Roucou P (2012) Simulating future trends in hydrological regime of a large Sudano-Sahelian catchment under climate change. J Hydrol 424-425:207-216. doi: 10.1016/j.jhydrol.2012.01.002

Rufino MC, Rowe EC, Delve RJ, Giller KE (2006) Nitrogen cycling efficiencies through resource-poor African crop-livestock systems. Agric Ecosyst Environ 112:261-282. doi:10.1016/j.agee. 2005.08.028

Rurinda J, Mapfumo P, van Wijk MT, Mtambanengwe F, Rufino MC, Chikowo R, Giller KE (2014) Comparative assessment of maize, finger millet and sorghum for household food security in the face of increasing climatic risk. Eur J Agron 55: 29-41. doi:10.1016/j.eja.2013.12.009

Rusinamhodzi L, Corbeels M, Van Wijk MT et al (2011) A metaanalysis of long-term effects of conservation agriculture on maize grain yield under rain-fed conditions. Agron Sustain Dev 31:657-673. doi:10.1007/s13593-011-0040-2

Rusinamhodzi L, Corbeels M, Zingore S, Nyamangara J, Giller K (2013) Pushing the envelope? Maize production intensification and the role of cattle manure in recovery of degraded soils in smallholder farming areas of Zimbabwe. Field Crop Res 147:40-53. doi:10.1016/j. fcr.2013.03.014

Sauerborn J, Sprich H, Mercer-Quarshie H (2000) Crop rotation to improve Agricultural production in sub-Saharan Africa. J Agron Crop Sci 184:67-72

Schittenhelm S, Schroetter S (2014) Comparison of drought tolerance of maize, sweet sorghum and sorghum-sudangrass hybrids. J Agron Crop Sci 200:46-53. doi:10.1111/jac.12039

Schlenker W, Lobell DB (2010) Robust negative impacts of climate change on African agriculture. Environ Res Lett 5:014010. doi: 10.1088/1748-9326/5/1/014010

Seo SN (2010) Is an integrated farm more resilient against climate change? A micro-econometric analysis of portfolio diversification in African agriculture. Food Policy 35:32-40. doi:10.1016/j. foodpol.2009.06.004

Sheahan M, Barrett CB (2014) Understanding the agricultural input landscape in sub-Saharan Africa. Recent plot, household, and community-level evidence. World Bank Policy Research Working Paper 7014. Washington D.C., USA

Siddique KHM, Johansen C, Turner NC et al (2012) Innovations in agronomy for food legumes. A review. Agron Sustain Dev 32:4564. doi:10.1007/s13593-011-0021-5

Snapp SS, Rohrbach DD, Simtowe F, Freeman HA (2002) Sustainable soil management options for Malawi: can smallholder farmers grow more legumes? Agric Ecosyst Environ 91:159-174. doi:10.1016/ S0167-8809(01)00238-9

Snapp SS, Blackie MJ, Gilbert RA et al (2010) Biodiversity can support a greener revolution in Africa. Proc Natl Acad Sci U S A 107:20840-20845. doi:10.1073/pnas.1007199107

Staggenborg SA, Dhuyvetter KC, Gordon WB (2008) Grain sorghum and corn comparisons: yield, economic, and environmental responses. Agron J 100:1600-1604. doi:10.2134/agronj2008.0129 
Stroosnijder L (2009) Modifying land management in order to improve efficiency of rainwater use in the African highlands. Soil Tillage Res 103:247-256. doi:10.1016/j.still.2008.05.019

Tagoe SO, Horiuchi T, Matsui T (2010) Effects of carbonized chicken manure on the growth, nodulation, yield, nitrogen and phosphorus contents of four grain legumes. J Plant Nutr 33:684 700. doi:10.1080/01904160903575915

Tesso TT, Ejeta G (2011) Integrating multiple control options enhances management and sorghum yield on heavily infested soils. Agron J 103:1464-1471. doi:10.2134/agronj2011.0059

Thierfelder C, Wall PC (2009) Effects of conservation agriculture techniques on infiltration and soil water content in Zambia and Zimbabwe. Soil Tillage Res 105:217-227. doi:10.1016/j.still.2009. 07.007

Thierfelder C, Cheesman S, Rusinamhodzi L (2012) A comparative analysis of conservation agriculture systems: benefits and challenges of rotations and intercropping in Zimbabwe. Field Crop Res 137:237250. doi:10.1016/j.fcr.2012.08.017

Thierfelder C, Mwila M, Rusinamhodzi L (2013) Conservation agriculture in eastern and southern provinces of Zambia: long-term effects on soil quality and maize productivity. Soil Tillage Res 126:246258. doi:10.1016/j.still.2012.09.002

Thornton PK, Jones PG, Alagarswamy G et al (2010) Adapting to climate change: agricultural system and household impacts in East Africa. Agric Syst 103:73-82. doi:10.1016/j.agsy.2009.09.003

Tilander Y, Bonzi M (1997) Water and nutrient conservation through the use of agroforestry mulches, and sorghum yield response. Plant Soil 197:219-232

Traore B, Corbeels M, van Wijk MT, Rufino MC, Giller KE (2013) Effects of climate variability and climate change on crop production in southern Mali. Eur J Agron 49:115-125. doi:10.1016/j.eja2013. 04.004

Traore B, van Wijk MT, Descheemaeker K, Corbeels M, Rufino MC, Giller KE (2014) Evaluation of climate adaptation options for Sudano-Sahelian cropping systems. Field Crop Res 156:63-75. doi:10.1016/j.fcr2013.10.014

Tuinstra MR, Soumana S, Al-Khatib K et al (2009) Efficacy of herbicide seed treatments for controlling infestation of sorghum. Crop Sci 49: 923-929. doi:10.2135/cropsci2008.06.0357

Twomlow S, Rohrbach D, Dimes J et al (2010) Micro-dosing as a pathway to Africa's Green Revolution: evidence from broad-scale on-farm trials. Nutr Cycl Agroecosyst 88:3-15. doi:10.1007/ s10705-008-9200-4

Valbuena D, Erenstein O, Homann-Kee Tui S et al (2012) Conservation agriculture in mixed crop-livestock systems: scoping crop residue trade-offs in sub-Saharan Africa and South Asia. Field Crop Res 132:175-184. doi:10.1016/j.fcr.2012.02.022

Vanlauwe B (2013) Integrated soil fertility management — a concept that could boost soil productivity. Rural 21: the International Journal for Rural Development 47:34-37

Vanlauwe B, Pypers P, Birachi EA, Nyagaya M, Van Schagen B, Huising J, Ouma E, Blomme G, Van Asten P (2012) Integrated soil fertility management in Central Africa: experiences of the consortium for improving agriculture-based livelihoods in Central Africa (CIALCA). In: Hershey $\mathrm{CH}$ (ed) Eco-Efficiency: from vision to reality. Centro Internacional de Agricultura Tropical (CIAT), Cali, CO. $17 \mathrm{p}$

Venne J, Beed F, Avocanh A, Watson A (2009) Integrating Fusarium oxysporum f. sp. strigae into cereal cropping systems in Africa. Pest Manag Sci 65:572-580. doi:10.1002/ps.1741

Waddington SR, Li X, Dixon J et al (2010) Getting the focus right: production constraints for six major food crops in Asian and African farming systems. Food Secur 2:27-48. doi:10.1007/ s12571-010-0053-8

Wilson TD, Brook RM, Tomlinson HF (1998) Interactions between nere (Parkia biglobosa) and under-planted sorghum in a parkland system in Burkina Faso. Exp Agric 34:85-99

Wortmann CS (2001) Nutrient dynamics in a climbing bean and sorghum crop rotation in the Central Africa Highlands. 61:267-272

Zaongo CGL, Wendt CW, Lascano RJ, Juo ASR (1997) Interactions of water, mulch and nitrogen on sorghum in Niger. Plant Soil 197:119126

Zingore S, Delve RJ, Nyamangara J, Giller KE (2008) Multiple benefits of manure: the key to maintenance of soil fertility and restoration of depleted sandy soils on African smallholder farms. Nutr Cycl Agroecosyst 80:267-282

Zinyengere N, Crespo O, Hachigonta S (2013) Crop response to climate change in southern Africa: a comprehensive review. Global Planet Chang 111:118-126. doi:10.1016/j.gloplacha.2013.08.010

Zougmoré R, Mando A, Ringersma J, Stroosnijder L (2003) Effect of combined water and nutrient management on runoff and sorghum yield in semiarid Burkina Faso. Soil Use Manag 19:257-264. doi: 10.1079/SUM2003199 